\title{
Mechanisms underlying dual effects of serotonin during development of Helisoma trivolvis (Mollusca)
}

\author{
Konstantin Glebov ${ }^{1,2+}$, Elena E Voronezhskayaa ${ }^{2,3 \dagger}{ }^{\dagger}$ Marina Yu Khabarova ${ }^{3}$, Evgeny Ivashkin ${ }^{4}$, Leonid P Nezlin ${ }^{3}$ \\ and Evgeni G Ponimaskin ${ }^{2,5^{*}}$
}

\begin{abstract}
Background: Serotonin (5-HT) is well known as widely distributed modulator of developmental processes in both vertebrates and invertebrates. It is also the earliest neurotransmitter to appear during neuronal development. In aquatic invertebrates, which have larvae in their life cycle, 5-HT is involved in regulation of stages transition including larval metamorphosis and settlement. However, molecular and cellular mechanisms underlying developmental transition in aquatic invertebrate species are yet poorly understood. Earlier we demonstrated that in larvae of freshwater molluscs and marine polychaetes, endogenous 5-HT released from the neurons of the apical sensory organ (ASO) in response to external stimuli retarded larval development at premetamorphic stages, and accelerated it at metamorphic stages. Here we used a freshwater snail Helisoma trivolvis to study molecular mechanisms underlying these dual developmental effects of 5-HT.
\end{abstract}

Results: Larval development of $\mathrm{H}$. trivolvis includes transition from premetamorphic to metamorphic stages and shares the main features of metamorphosis with free-swimming aquatic larvae. Three types of $5-\mathrm{HT}$ receptors $\left(5-\mathrm{HT}_{1}-, 5-\mathrm{HT}_{4}\right.$ - and $5-\mathrm{HT}_{7}$-like) are functionally active at premetamorphic (trochophore, veliger) and metamorphic (veliconcha) stages, and expression patterns of these receptors and respective $\mathrm{G}$ proteins undergo coordinated changes during development. Stimulation of these receptors modulated cAMP-dependent regulation of cell divisions. Expression of $5-\mathrm{HT}_{4}$ - and $5-\mathrm{HT}_{7}$-like receptors and their downstream $G_{s}$ protein was down-regulated during the transition of pre- to metamorphic stage, while expression of $5-\mathrm{HT}_{1}$-like receptor and its downstream $\mathrm{G}_{i}$ protein was upregulated. In accordance with relative amount of these receptors, stimulation of 5-HTRs at premetamorphic stages induces developmental retardation, while their stimulation at metamorphic stages induces developmental acceleration.

Conclusions: We present a novel molecular mechanism that underlies stage-specific changes in developmental tempo of $\mathrm{H}$. trivolvis larvae in response to endogenous 5-HT produced by the neurons of the ASO. We suggest that consecutive changes in expression patterns of different receptors and their downstream partners in the course of larval development represent the molecular base of larval transition from premetamorphic (non-competent) to metamorphic (competent) state.

Keywords: Serotonin receptors, Helisoma trivolvis, Development, Metamorphosis, Trochophore, Larval competence

\footnotetext{
* Correspondence: Ponimaskin.Evgeni@mh-hannover.de

${ }^{\dagger}$ Equal contributors

2DFG-Research Center Molecular Physiology of the Brain (CMPB), Göttingen,

Germany

${ }^{5}$ Department of Cellular Neurophysiology, Carl-Neuberg-Str. 1, 30625

Hannover, Germany

Full list of author information is available at the end of the article
}

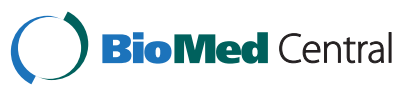

(c) 2014 Glebov et al.; licensee BioMed Central Ltd. This is an Open Access article distributed under the terms of the Creative Commons Attribution License (http://creativecommons.org/licenses/by/2.0), which permits unrestricted use, distribution, and reproduction in any medium, provided the original work is properly credited. The Creative Commons Public Domain Dedication waiver (http://creativecommons.org/publicdomain/zero/1.0/) applies to the data made available in this article, unless otherwise stated. 


\section{Background}

Serotonin (5-hydroxytryptamine, 5-HT) is well known not only as neurotransmitter modulating wide range of neurophysiological processes, but also as one of the earliest to appear and widely distributed modulator of development in both vertebrate and invertebrate animals [1-8]. The hypothesis that 5 -HT plays a critical role as growth regulatory signal in the developing brain $[3,9,10]$ was confirmed by subsequent studies $[8,11]$. In addition to its role in neuronal development, $5-\mathrm{HT}$ is implicated in regulation of various developmental processes, i.e., meiosis reinitiating, cell divisions, morphogenetic movements, and left-right axis patterning [4-6,12-15].

The great majority of aquatic animals have a complex biphasic life cycle in which a free-swimming or encapsulated larval phase precedes juvenile and adult form. Larval development is a complex process controlled by various external and internal factors $[16,17]$, and 5 -HT has been shown to be involved in regulation of stages transition including larval metamorphosis and settlement [16]. For example, 5-HT mediated the induction of dauer larva formation in the nematode Caenorhabditis elegans $[18,19]$, stimulated metamorphosis in hydroid Eudendrium racemosum in the presence of a natural cue [20], induced metamorphosis in scyphozoan and hydrozoan planulae $[21,22]$, and induced larval settlement in barnacles [23] and molluscs [24,25]. In ascidian larvae, 5-HT signalling was suggested to trigger metamorphosis [26]. In all listed studies, 5-HT was suggested to act via larval nervous system and downstream 5-HT receptors. Thus, 5-HT receptors (5-HTRs) with pharmacological profiles similar to those of mammalian $5-\mathrm{HT}_{1} \mathrm{R}$ and $5-\mathrm{HT}_{2} \mathrm{R}$ were demonstrated to mediate rotational response to hypoxia in trochophore larvae of pulmonate snail Helisoma trivolvis [27-29], and $5-\mathrm{HT}_{1} \mathrm{R}$ and $5-\mathrm{HT}_{7} \mathrm{R}$ were cloned [30]. Two receptors with high and low affinities for serotonin mediated settlement in cyprid larvae of barnacle Balanus amphitrite [23] and $\mathrm{G}$ protein-coupled receptor homologues to $5-\mathrm{HT}_{1} \mathrm{R}$ were cloned for this species [31]. Pharmacological analysis also suggested involvement of $5-\mathrm{HT}_{1} \mathrm{R}$ in induction of metamorphosis of competent planula of hydroid E. racemosum [20]. However, information about 5-HT receptor subtypes and particularly about their signal transduction systems underlying effects of 5-HT during larval development and metamorphosis is scanty, and usually only one particular developmental stage (either early premetamorphic, or metamorphic) was examined, whereas changes during development were not traced.

It is known that presence of conspecific adults can influence larval development. Thus, water-born chemicals from conspecific adults delayed hatching in crustaceans $[32,33]$ and accelerated time-to-hatching in the marine gastropod Nucella lamellose [34]. Previously we found that larvae of freshwater molluscs $L$. stagnalis and $H$. trivolvis and marine polychaete Platynereis dumerilii can regulate developmental tempo (the speed of transition from one stage to another) in response to a chemical signal emitted by starved conspecific adults. In our experiments, the signal retarded larval development at premetamorphic stages and accelerated it at metamorphic stages $[35,36]$. We also demonstrated that changes in the developmental rate in respond to the chemical signal were transmitted via 5-HT neurons of the apical sensory organ (ASO) and 5-HT released by these neurons was involved in developmental regulation [35]. However, molecular mechanisms responsible for stage-dependent dual effects of endogenous 5-HT remain unknown.

The ASO is a specialized and highly evolutionary conserved larval structure composed of sensory and motor neurons, which allow the larvae to adapt its behaviour to changing environment [37-40]. A characteristic feature of the ASO across larvae of diverse invertebrate phyla is a group of serotonergic cells $[1,39,41-43]$. In many aquatic invertebrates, these neurons are the first to differentiate and represent the central component of the larval nervous system [41-45]. The neurons of the ASO coordinate ciliary activity for swimming and feeding at early larval stages $[27,29,46,47]$ and play a critical role in perceiving settlement-inducing cues leading to metamorphic transition in competent larvae $[17,24,48,49]$. In all this cases, 5 -HT produced and released by apical neurons exerts its effects through activation of respective 5 -HT receptors.

In the present study we used a freshwater gastropod Helisoma trivolvis to analyse the molecular mechanisms underlying the physiological effects of 5-HT during premetamorphic and metamorphic larval stages. We consider $H$. trivolvis as a suitable model to address this question by several reasons. Firstly, although the whole development of $H$. trivolvis until the stage of a juvenile snail occurs inside egg capsules, the embryos pass the same developmental stages as free-swimming larvae of trochophore animals: trochophore, veliger and veliconcha $[35,47,50,51]$, and these stages can be easily determined according to the set of morphological and morphometric characters (larval ciliary bands and apical neurons, as well as the degree of shell, tentacles and foot development, eye pigmentation, and type of locomotion). Secondly, normal development of all embryos within one egg mass is highly synchronous, and the length of the embryos at subsequent developmental stages precisely correlates with the above listed morphological and behavioural characters [35], thus measuring the length can be used as a valid indicator of stage progression. Thirdly, two 5-HT receptors in H. trivolvis $\left(5-\mathrm{HT}_{1} \mathrm{R}\right.$ and $\left.5-\mathrm{HT}_{7} \mathrm{R}\right)$ have been recently cloned [30], thus making possible to monitor the relative expression of these receptors at different developmental stages. 
Using pharmacological and molecular approaches we demonstrate functional involvement of at least three types of 5-HTRs in the regulation of $H$. trivolvis developmental tempo. We found that activation of $5-\mathrm{HT}_{4}$-like receptor $\left(5-\mathrm{HT}_{4} \mathrm{R}\right)$ and $5-\mathrm{HT}_{7}$-like receptor $\left(5-\mathrm{HT}_{7} \mathrm{R}\right)$ induced developmental retardation, while activation of $5-\mathrm{HT}_{1}$-like receptor $\left(5-\mathrm{HT}_{1} \mathrm{R}\right)$ induced developmental acceleration. This work has appeared previously in abstract form [52]. Expression patterns of $5-\mathrm{HT}_{1} \mathrm{R}, 5-\mathrm{HT}_{7} \mathrm{R}$ and corresponding $G_{i}$ and $G_{s}$ proteins changed in a certain manner at premetamorphic and metamorphic developmental stages. Based on our experimental results we suggest a molecular mechanism by which 5 -HT regulates larval development in alternative ways depending on the developmental stage (premetamorphic or metamorphic) the larva passes.

\section{Methods}

\section{Animals and identification of developmental stages}

Egg masses were collected from $H$. trivolvis inbred colony maintained at the Institute of Developmental Biology, Moscow. Ten to twelve mature snails were raised in plastic tanks with a $16 / 8 \mathrm{~h} \mathrm{light/dark} \mathrm{cycle} \mathrm{at} 23-25^{\circ} \mathrm{C}$ and fed on lettuce. Freshly laid egg masses were collected daily and transferred to Petri dishes (Falcon) containing boiled filtered $(0.2 \mu \mathrm{M}$ Millipore) pond water. Each adult snail produces daily 1-2 transparent egg masses containing 10-30 eggs each.

Embryonic development was staged on the basis of specific transient larval characters such as dorsolateral ciliary bands (the remnants of the prototrochal ciliary band), pedal ciliary band and apical 5-HT-like immunoreactive neurons (remnants of the ASO), as well as developing adult morphological and behavioural features: the degree of shell, tentacles and foot development, eye pigmentation, and type of locomotion [50,51]. Stage 19 corresponds to early premetamorphic trochophore $(20 \%$ of normal embryonic development or n.e.d.), stage 23 - middle veliger ( $45 \%$ n.e.d.), stage 25 - veliconcha ( $65 \%$ n.e.d.), stage 27 - the last larval stage ( $85 \%$ n.e.d.) and stage 28 - early adult-like form ( $90 \%$ n.e.d.).

Since the increase in size of the embryos is in correlation with successive developmental stages [35,50], we checked what size corresponds to particular stages determined according to the set of morphological, morphometric and behavioural characters (Table 1). In subsequent experiments, the length of embryos was used as valid indicator of stage progression. Egg masses at appropriate developmental stages were selected for experiments. Each egg contains a single embryo and development of all embryos in each egg mass is synchronous under standard conditions. However, embryos within a single egg mass develop independently and their responses to external stimuli can vary, thus each embryo can be treated as an independent sample.
Table 1 Normal development of $\boldsymbol{H}$. trivolvis

\begin{tabular}{ccccc}
\hline \multicolumn{2}{c}{ Stage name } & $\begin{array}{c}\text { Stage after } \\
\text { Meshcheriakov }\end{array}$ & Stage,\% & $\begin{array}{c}\text { Size, mm } \\
\text { (min - max) }\end{array}$ \\
\hline Trochophore & Early & 19 & 20 & $0.16-0.19$ \\
& Middle & 20 & 25 & $0.20-0.24$ \\
\multirow{4}{*}{ Veliger } & Late & 21 & 30 & $0.25-0.31$ \\
& Early & 22 & 35 & $0.32-0.40$ \\
& Middle & 23 & 45 & $0.41-0.47$ \\
Metamorphic & Late "hippo" & 24 & 55 & $0.48-0.56$ \\
& Veliconcha & 25 & 65 & $0.57-0.61$ \\
& & 26 & 75 & $0.62-0.66$ \\
Adult-like & & 27 & 85 & $0.67-0.72$ \\
& & 28 & 90 & $0.73-0.78$ \\
& & 29 & 100 & $0.74-0.79$ \\
\hline
\end{tabular}

Interrelations between developmental stages after Mescheriakov [51], timing of embryogenesis in\%, and the length of specimens in $\mathrm{mm}$ are shown. Five hundred specimens were measured.

\section{Pharmacological treatments}

The following drugs were used (Tocris, Bristol, UK, unless other specified): $\alpha$-methylserotonin maleate, 5 -carboxyamido-tryptamine maleate (5-CT), 2,5-dimethoxy-4-iodoamphetamine (DOI), forskolin (Sigma), GR113808, trimethyl 5-HT iodide (5-HTQ), ( \pm )-8-Hydroxy-2-dipropylaminotetralin hydrobromide (8-OH-DPAT), methiothepin maleate, pimozide, RS67333, RS67506, SB269970, (S)-WAY100135 dihydrochloride, dibutyryl-cAMP sodium salt (db-cAMP), MDL 12330A hydrochloride, H 89 dihydrochloride. All solutions were prepared as $10 \mathrm{mM}$ stocks and stored at $-20^{\circ} \mathrm{C}$. RS67333 and GR113808 were prepared as $10 \mathrm{mM}$ solutions in DMSO. Equal amount of DMSO was added to the controls, and was shown to have no effect on the development. Receptor antagonists were applied $10 \mathrm{~min}$ before the agonists were added. For pharmacological experiments, egg masses were transferred into $30 \mathrm{~mm}$ dishes containing $2 \mathrm{ml}$ of solution in appropriate concentration, the dishes were kept in a dark humid chamber at $25^{\circ} \mathrm{C}$ and solutions were changed daily.

In preliminary experiments, solutions of the agonists (RS67333, 5CT, 8-OH-DPAT) were changed after 12, 24,48 , and 72 hours. No significant differences were observed in the effects of the drugs when changed after 12 to 48 hours. When the solutions were changed after 72 hours, the effects became weaker. Thus, 24 hours were selected for all subsequent experiments. Efficacy of the drugs tested was determined according to the following criteria: the effects had to be significant, concentration dependent and manifest themselves at micromolar concentrations. In this case, we considered the drug to penetrate the egg casing and reach specific targets.

Egg masses containing 15-20 eggs were selected for each experiment. At least three sets of experiments were made 
for each treatment utilizing a blind experimental method to ensure impartiality. For investigation of cell divisions, egg masses were incubated in solutions of respective agonists during $10 \mathrm{~h}$ at $25^{\circ} \mathrm{C}$ then fixed and proceeds for immunocytochemistry.

\section{Immunocytochemistry}

Embryos at the appropriate stage were gently removed from the egg capsules, washed from the egg fluid in water and then fixed in $4 \%$ paraformaldehyde in $0.01 \mathrm{M}$ phosphate buffer (Sigma, $\mathrm{PB}, \mathrm{pH} 7.4$ ) for $4 \mathrm{~h}$ at $10^{\circ} \mathrm{C}$ and further processed as described earlier [35]. To visualize serotonergic neurons and ciliary bands, the specimens were incubated in a mixture of anti-5-HT (ImmunoStar, Hudson, USA, \#20080, polyclonal, rabbit, dilution 1:3000) and antiacetylated $\alpha$-tubulin antibody (Sigma-Aldrich, Munich, Germany, T-6793, monoclonal, mouse, dilution 1:4000) in PB with $10 \%$ normal goat serum, $0.25 \%$ bovine serum albumin, 5\% Triton X-100 (TX), and $0.03 \%$ sodium azide (PB-TX) for $72 \mathrm{~h}$ at $10^{\circ} \mathrm{C}$. The specimens were washed in PB three times for $20 \mathrm{~min}$, incubated in a mixture of goatanti-rabbit Alexa 488-conjugated IgG and goat-anti-mouse Alexa 633-conjugated IgG (Molecular Probes, USA), both diluted 1:800 in PB-TX, for $12 \mathrm{~h}$ at $10^{\circ} \mathrm{C}$. Finally, the samples were washed twice in $\mathrm{PB}$, immersed in $70 \%$ glycerol in PB and mounted on glass slides. Morphological data presented in this study are based upon examination of at least fifteen embryos from at least three different egg masses for each particular stage described.

To visualize cell divisions, fixed embryos were washed in $\mathrm{PB}$ and incubated with the antibody against phosphorylated Ser28 histone H3 (Sigma-Aldrich, H9908) diluted 1:1000 in PB-TX for $72 \mathrm{~h}$ at $10^{\circ} \mathrm{C}$. The specimens were washed three times in $\mathrm{PB}$ and incubated in goat-anti-rat IgG conjugated with Alexa 546 (1:800 dilution in PB-TX) for $12 \mathrm{~h}$ at $10^{\circ} \mathrm{C}$. Samples were incubated for $10 \mathrm{~min}$ in DAPI $(2.5 \mu \mathrm{g} / \mathrm{ml}$ in PB), washed two times in $\mathrm{PB}$, immersed in $70 \%$ glycerol in $\mathrm{PB}$ and mounted on glass slides.

Stained embryos were examined as whole mounts under TCS SP5 laser-scanning microscope (Leica Microsystems, Wetzlar, Germany) with appropriate configuration settings. To determine the exact position of cells and ciliary structures, fluorescence images were combined with transmission light images. The number of nuclei stained with the antibody was counted from the maximal intensity projections using Image (NIH, Bethesda, USA).

For illustrations, series of optical sections $(0.7 \mu \mathrm{M}$ step size, from the upper till the lower surfaces of the embryo) were projected into single images with greater focal depth using LAS-AF software (Leica Microsystems) and exported as TIFF images. All images were linearly adjusted for contrast and brightness and assembled into plates using Photoshop CS5 (Adobe, San Jose, USA).

\section{Measurements and statistics}

The length of embryos was measured twice a day as described elsewhere [35]. Only the embryos being in the strict side view position were measured. Results were expressed as mean \pm standard deviation (s.d.) or standard error of the mean (s.e.m.) and normalized to the respective control. The linear fitting of larval length and the slope coefficients were calculated using MS Excel 2007. To double check identification of developmental stages, some embryos were processed for immunocytochemical visualization of 5HT neurons and ciliary structures. The significance of differences among groups was evaluated using one-way ANOVA, differences were considered significant at $p<0.05$.

\section{Quantitative real-time RT-PCR}

$H$. trivolvis embryos were aspirated from eggs with a glass micropipette and immediately frozen in liquid nitrogen. Ten embryos from three different egg masses were used for each developmental stage at one trial. Three independent trials were performed for each stage. To release total RNA, cells were destroyed by repeated thawing and freezing in liquid nitrogen. Crushed embryos were incubated with RNase-free DNase I (2 U/sample, Life technologies) to remove genomic DNA contamination. After the inactivation of DNase I by heating, cDNA was synthesized by the Superscript II reverse transcription kit with random hexamer primers (Life technologies). Quantitative real-time PCR (ABI PRISM 7000, Life technologies, Bethesda, USA) was performed by using gene-specific primers and SYBR Green Master Mix kit (Life technologies). The following primers were used to amplify cDNA fragments of $5-\mathrm{HT}_{1}$ receptor gene (GenBank accession no. AY395746): sense (5'-TCA ACA GCC TAC TGA ACC CTA TCA-3') and antisense (5'-TCG GTG GCC CCG TCT ATA-3'). The following primers were used for the $5-\mathrm{HT}_{7}$ receptor (GenBank accession no. AY395747): sense (5'-CCT CTG CGG TTA TGT CAA-3') and antisense (5'-ACC GGA ACA GGA GAA TCT CTT TAA A-3'). For quantitative analysis, $\beta$-actin (GenBank accession no. AF435729) was analyzed in parallel by using sense $\left(5^{\prime}\right.$-CTT CAA CAC ACC AGC TAT GTA CGT T-3') and antisense (5'-TTA CAC CGT CAC CAG AGT CCA T-3') primers. The analysis was performed using $\Delta \Delta \mathrm{Ct}$ method according to the procedure described on: http://www3.appliedbiosystems.com/ cms/groups/mcb_support/documents/generaldocuments/cms_ 042115.pdf.

\section{GTPgamma-Eu binding assay}

$H$. trivolvis embryos at developmental stage 23 were removed from the egg capsules, washed with $\mathrm{PB}$, resuspended in extraction buffer $(10 \mathrm{mM}$ Tris- $\mathrm{HCl}, \mathrm{pH} 7,4 ; 1 \mathrm{mM}$ EDTA; $150 \mathrm{mM} \mathrm{NaCl} ; 1 \mathrm{mM}$ DTT) and homogenized. The homogenate was centrifuged at $5.000 \mathrm{~g}$ for $5 \mathrm{~min}$ at $+4^{\circ} \mathrm{C}$, and resulting supernatant was centrifuged at $14.000 \mathrm{~g}$ for 
$50 \mathrm{~min}$. The membrane pellets were resuspended in TE buffer ( $\mathrm{pH} 7.4)$ and stored at $-84^{\circ} \mathrm{C}$. For the GTP $\gamma$-EU assay membranes were resuspended in assay buffer (50 mM Tris-HCl, pH 7.4; 2 mM EDTA; 100 mM NaCl; $3 \mathrm{mM} \mathrm{MgCl}$ ). 5-HT-promoted binding of GTPY-Eu to defined G-proteins was performed using Perkin Elmer DELFIA GTP-Eu Binding Kit (Cat. No. AD0167) according to the manufacturer instructions and as described previously [53]. Briefly, $4 \mu \mathrm{l}$ of membranes prepared from the embryos (10 $\mu \mathrm{g}$ per probe) were resuspended in $94 \mu \mathrm{l}$ of assay buffer (50 mMTris- $\mathrm{HCl}(\mathrm{pH} 7.4)$ containing $2 \mathrm{mM}$ EDTA, $100 \mathrm{mMNaCl}, 3 \mathrm{mM} \mathrm{MgCl}, 1 \mu \mathrm{M}$ GDP). Serotonin at final concentration of $10 \mu \mathrm{M}$ was added and membranes were incubated at RT for $10 \mathrm{~min}$. FMRFamide at final concentration of $10 \mu \mathrm{M}$ was used as positive control of $\mathrm{G}_{\mathrm{q}}$ activation. After adding $1 \mu \mathrm{l}$ GTP-Eu (PerkinElmer), samples were incubated for $1.5 \mathrm{~h}$ at RT. The reaction was terminated by adding $200 \mu \mathrm{l}$ of termination buffer $(50 \mathrm{mM}$ Tris- $\mathrm{HCl}, \mathrm{pH} 7.5 ; 20 \mathrm{mM}$ $\mathrm{MgCl}_{2} ; 150 \mathrm{mM} \mathrm{NaCl} ; 0,5 \% \mathrm{NP}-40 ; 200 \mu \mathrm{g} / \mathrm{ml}$ aprotinin; $100 \mu \mathrm{M}$ GDP; $100 \mu \mathrm{M}$ GTP) for $15 \mathrm{~min}$ on ice. The samples were incubated with $10 \mu \mathrm{l}$ of antibodies against $\mathrm{G}_{\mathrm{s}}$ and $\mathrm{G}_{\mathrm{q}}$, (sc823, sc392, respectively, all Santa Cruz, Dallas, USA) at RT followed by incubation with $75 \mu \mathrm{l}$ of a Sepharose-Protein G conjugate (Sigma). Antibodies against anti-acetylated $\alpha$-tubulin (T-6793, Sigma-Aldrich, Munich, Germany) were used as a control for the unspecific binding during immunoprecipitation. Immunoprecipitates were washed three times in termination buffer, heated at $99^{\circ} \mathrm{C}$ for $3 \mathrm{~min}$ in $0.2 \mathrm{ml}$ of $0.5 \%$ SDS, centrifuged at $13.000 \mathrm{~g}$ for $5 \mathrm{~min}$ and the fluorescence intensity of supernatant was measured at $615 \mathrm{~nm}$ in multi-fluorescence plate reader Mithras LB680 (Berthold).

\section{Western blot}

Expression of the 5- $\mathrm{HT}_{1} \mathrm{R}, \alpha$-tubulin, $\mathrm{G}_{\mathrm{s}^{-}}, \mathrm{G}_{\mathrm{q}^{-}}$and $\mathrm{G}_{\mathrm{i}^{-}}$ protein was studied using membrane preparations of $H$. trivolvis at stages 19, 23 and 25. Embryos were removed from the eggs, washed with $\mathrm{PB}$, resuspended in extraction buffer (10 mM Tris-HCl, pH 7.4, 1 mM EDTA, $150 \mathrm{mM}$ $\mathrm{NaCl}, 1 \mathrm{mM}$ DTT) and homogenized by a rotating pestle at 2000 r.p.m. 1000 embryos at stage 19, 600 at stage 23, and 400 at stage 25 were used for membrane preparation used for one trial. Tissue homogenate was centrifuged at $5.000 \mathrm{~g}$ for $5 \mathrm{~min}$ at $+4^{\circ} \mathrm{C}$, and the resulting supernatant was centrifuged at $14.000 \mathrm{~g}$ for 50 minutes. The membrane pellets were resuspended in TE buffer ( $\mathrm{pH}$ 7.4) and stored at $-84^{\circ} \mathrm{C}$. Preparations were analysed by SDS-PAGE on $12 \%$ acrylamide gel and visualized by filmless chemiluminescence analysis (PeqLab). Primary antibodies against $\alpha$-tubulin (Sigma-Aldrich, T-6793), 5- $\mathrm{HT}_{1 \mathrm{~A}} \mathrm{R}$ (sc-10801), 5- $\mathrm{HT}_{4} \mathrm{R}$ (sc-28959 and AS9459, [26]), 5- $\mathrm{HT}_{7} \mathrm{R}$ (sc-28963), $\mathrm{G}_{\mathrm{s}}$ and $\mathrm{G}_{\mathrm{i}}$ proteins (sc-823, sc-12798, respectively, all Santa Cruz, Dallas, USA) were used. Preincubation of the antibody with corresponding blocking peptide (sc-823P, sc-392P, sc-12798P, all Santa Cruz) was used to verify the specificity of response and resulted in elimination of specific bands. Five trials were performed for each developmental stage. For quantitative analysis, the Scan Pack 2.0 software (Biometra, Goettingen, Germany) was used.

\section{Results}

\section{Developmental analysis of Helisoma trivolvis}

Although the general development of freshwater gastropods has been previously described $[47,50,51,54,55]$, formation of transitory larval characters in $H$. trivolvis during the whole development has not been addressed in details. In H. trivolvis, initial cleavage resulted in formation of a ciliated trochophore larva (stage 19), which continually rotated in the egg fluid using dorsolateral and pedal ciliary bands. At this stage, two 5-HT-positive neurons were located dorsally to the mouth at the base of each dorsolateral ciliary band (Figure 1A). Each neuron had a dendritic knob that bore short cilia (Figure 1B). Thin branches emanated from the neuronal body and ran below the cilia of the dorsolateral band (Figure 1B). A thick primary neurite projected to the larval foot where numerous thin branches ramified underneath the pedal ciliary band (Figure 1C).

At stage 23, the larva became a middle veliger. Slow basal rotation started to alternate with transient periods of acceleration and occasional stops. Tentacular ciliary bands, symmetrical foot ciliary fields and numerous ciliary brushes added to dorsolateral and pedal ciliary bands (Figure 1D). In addition to apical serotonergic neurons, one 5-HT immunoreactive neuron in each cerebral ganglion and two neurons in each pedal ganglion were present at this stage (Figure 1D).

At stage 25, the larvae entered the metamorphosis. At the region of developing head, only tentacular ciliary bands and ciliary brushes could be observed, while dorsolateral ciliary bands were no more detected (Figure 1E). Additional ciliary brushes appeared on the lateral sides of the foot; symmetrical foot ciliary fields enlarged to merge, while the pedal ciliary band was still visible in the medial ventral area of the foot. Among 5-HT-immunopositive structures, commissures and connectives of the ganglionic ring as well as projections from the ganglionic neurons to the foot, tentacles and body wall became visible (Figure 1E). At this stage, up to three 5-HT positive neurons could be recognized in each pedal ganglion. Apical 5-HT neurons maintained their positions dorsolateral to the mouth and outside the rudiments of the cerebral ganglia. Ciliated dendritic knobs of these cells (Figure 1E, insert) as well as their projections and ramifications underneath the pedal ciliary bands were clearly visible.

During stages 26 and 27, metamorphosis progressed and by the end of stage 27 swimming movements ceased, the embryo attached its fully developed foot to the inner surface of the egg capsule and started to creep along it. By 

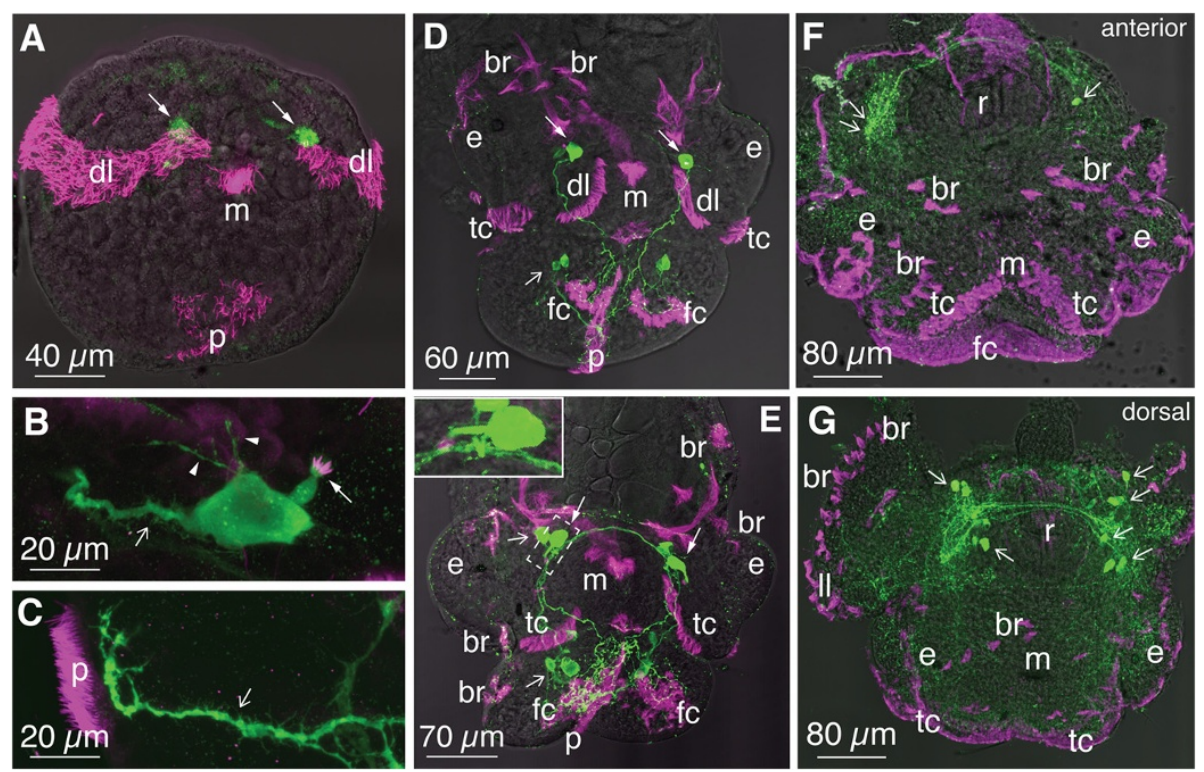

Figure 1 Development of ciliary structures and serotonergic system in H. trivolvis. Anti-a-tubulin (magenta) and anti-5-HT (green) immunostainings were imaged in a laser confocal microscope. In $\mathbf{A}$ and $\mathbf{D}-\mathbf{G}$, confocal images were combined with transmission light images. (A-C) Early trochophore (stage 19). (A) Two apical neurons (arrows), dorsolateral (dl) and pedal (p) ciliary bands are present. (B) Higher magnification of the apical neuron with dendritic knob, which bears short cilia (arrow), thin back branches (arrowheads), and primary neurite (open arrow). (C) Primary neurite (open arrow) with numerous thin branches underneath the pedal band of cilia (p). (D) Middle veliger in the beginning of metamorphosis (stage 23). Dorsolateral and pedal ciliary bands are complemented by foot ciliary fields (fc), tentacle ciliary fields (tc) and numerous body wall ciliary brushes (br). Two apical 5-HT neurons (arrows) and 5-HT positive cells within cerebral and pedal ganglia (open arrows) are present. (E) veliconcha in the middle of metamorphosis (stage 25). Dorsolateral ciliary bands are not visible, whereas all other ciliary structures are present. Insert, high magnification of the apical 5-HT neuron with ciliated dendritic knob. (F, G) H. trivolvis at the end of metamorphosis (stage 27), anterior (F) and dorsal (G) view. Serotonin-immunostaining is present in neurons of central ganglia (open arrows) and their peripheral processes only. Foot and tentacle ciliary fields (fc, tc) and numerous body wall ciliary brushes (br) are present. Note that 5-HT-immunopositive apical neurons, cilia on their dendritic knobs as well as dorsolateral and pedal ciliary bands are not visible. II - lung lobe, $m$ - mouth, e - eye, $r$ - radular sack.

the end of stage 27, the enlarged tentacular ciliary band and numerous body wall ciliary brushes were present at the head region. Enlarged symmetrical ciliary fields on the foot merged and formed a unified ventral ciliated surface of the foot, thus the pedal ciliary band could no longer be recognized (Figure 1F, G). 5-HT-immunopositive neurons of the cerebral ganglia and their peripheral projections to the body wall, tentacles and foot were visible, while neither the 5-HT immunopositive cell bodies of the apical neurons, nor their ciliated knobs could be detected (Figure 1F, G).

Thus, according to the presence of transitory larval characters such as dorsolateral and pedal ciliary bands and 5-HT-immunoreactive apical neurons, we consider developing $H$. trivolvis to be premetamorphic larvae at stages 19-23, metamorphic larvae at stages 25-27 and postmetamorphic adult-like forms at stage 28 and later. The duration of development from the trochophore (stage 19) till the adult-like postmetamorphic snail (stage 28) varied depending on the temperature. At $25 \pm 0.5^{\circ} \mathrm{C}$ it took $88 \pm 7.2 \mathrm{~h}(\mathrm{n}=289)$, at $23 \pm 0.5^{\circ} \mathrm{C} 108 \pm 11.6 \mathrm{~h}(\mathrm{n}=194)$ and at $21 \pm 0.5^{\circ} \mathrm{C} 162 \pm 15.5 \mathrm{~h}(\mathrm{n}=90)$. The temperature
$25 \pm 0.5^{\circ} \mathrm{C}$ was selected for all further experiments because at this temperature the development of embryos was the most synchronous.

\section{Larval development is bidirectionally regulated by activation of different 5 - $\mathrm{HT}$ receptors}

To study the roles of 5-HTRs in larval development of $H$. trivolvis, we used the set of specific agonists. Specimens were continuously incubated in drug-containing solutions starting from the trochophore stage until the end of metamorphosis (stages 19 and 28, respectively). Agonists of mammalian $5-\mathrm{HT}_{2} \mathrm{R}$ ( $\alpha$-methylserotonin and DOI) and $5-\mathrm{HT}_{3} \mathrm{R}(5-\mathrm{HTQ})$ in concentrations $1 \mu \mathrm{M}, 5 \mu \mathrm{M}$ and $10 \mu \mathrm{M}$ had no effect on embryonic development $(\mathrm{n}=40$ for each concentration for each drug tested). Incubation of larvae with RS67333 (agonist of the mammalian 5$\mathrm{HT}_{4} \mathrm{R}$ ) resulted in pronounced developmental retardation, which was expressed as elongation of each developmental stage and corresponding decrease in larval length compared to the controls at each observation point. This retardation started after $24 \mathrm{~h}$ of incubation and progressed by $84 \mathrm{~h}$ of incubation (Figure 2A, B). Significant retardation was 


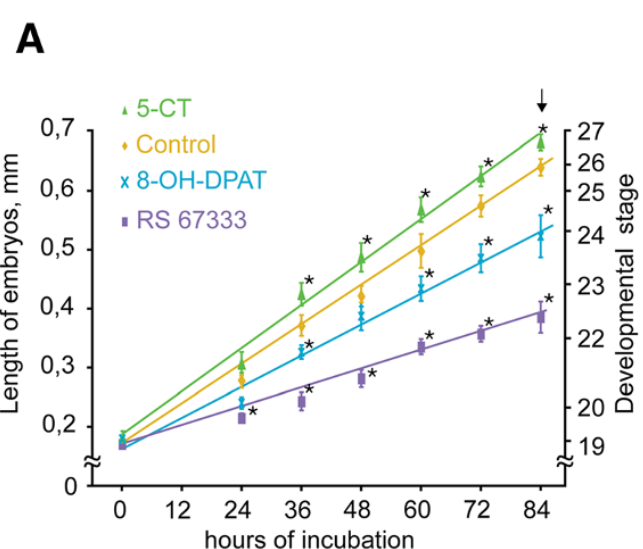

B
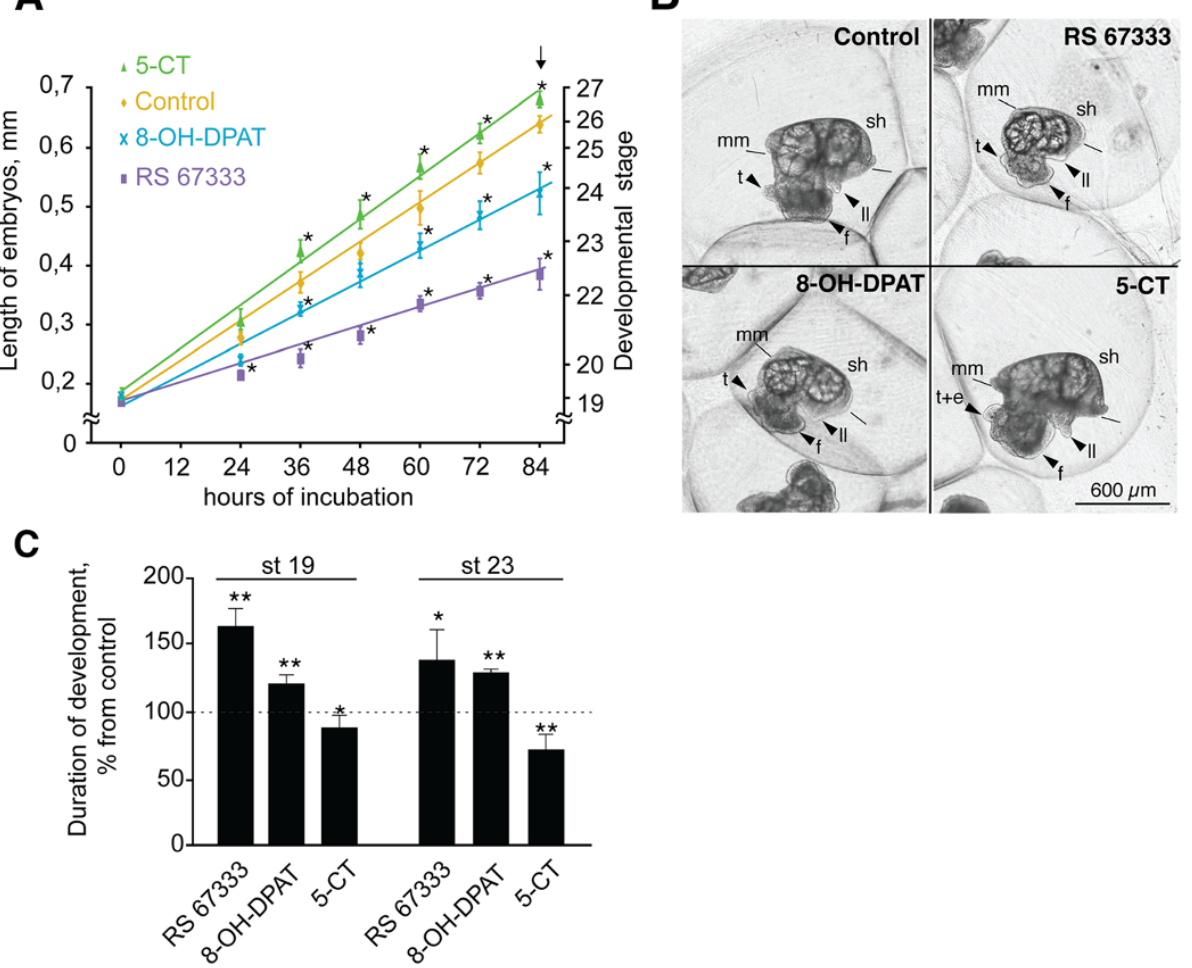

Figure 2 Effects of different agonists of 5-HT receptors on embryonic development of $\boldsymbol{H}$. trivolvis. (A) The length of embryos during the development under control conditions (control, $n=80)$ and after incubation with 5-HT ${ }_{4} R$ agonist RS67333 $(2.5 \mu M, n=80), 5-H T_{7} R$ agonist 8-OH-DPAT $(5 \mu \mathrm{M}, \mathrm{n}=80)$ and $5-\mathrm{HT}_{1} \mathrm{R}$ agonist 5-CT $(1 \mu \mathrm{M}, \mathrm{n}=80)$. Development is significantly retarded after RS67333 and 8-OH-DPAT, and accelerated after 5-CT treatment. Linear fitting slope coefficient $(k)$ is 0.068 for control $\left(R^{2}=0.99\right), 0.031$ for $R S 67333\left(R^{2}=0.98\right), 0.052$ for $8-O H-D P A T\left(R^{2}=0.99\right)$, and 0.075 for $5-C T\left(R^{2}=0.99\right)$. (B) Overview of representative larvae after $84 \mathrm{~h}$ of incubation in the above mentioned drugs, equal magnification. The size of embryos strongly corresponds to certain developmental stages. At the time when the control animal is in the end of metamorphosis and represents a miniature snail, the embryos incubated with RS67333 and 8-OH-DPAT are still at the premetamorphic stage. On the contrary, the embryo incubated with 5-CT reaches the postmetamorphic adult-like stage and is bigger than the control. (See also supplementary materials Movies 1 to 3 ). $f-$ foot, II - lung lobe,

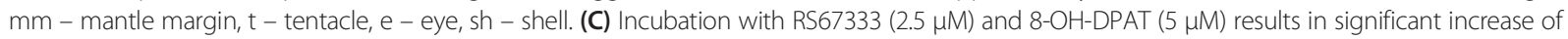
both total duration of development and duration of metamorphosis. Retardation effect of RS67333 is more pronounced, when treatment starts at stage 19. Incubation with 5-CT (1 $\mu \mathrm{M})$ reduces developmental time and duration of metamorphosis with the strongest effect at stage 23 ( $n=60$ for each group). Data are shown as mean \pm s.d. ( $\left.{ }^{*}, p<0.05 ;{ }^{* *}, p<0.01\right)$.

also obtained after chronic treatment of embryos with 8-OH-DPAT (agonist of $5-\mathrm{HT}_{7} \mathrm{R}$ and partial agonist of $5-\mathrm{HT}_{1} \mathrm{R}$; Figure $\left.2 \mathrm{~A}, \mathrm{~B}\right)$.

In contrast, prolonged incubation with 5-CT (agonist of $5-\mathrm{HT}_{1} \mathrm{R}$ and partial agonist of $\left.5-\mathrm{HT}_{7} \mathrm{R}\right)$ accelerated larval development, so the experimental embryos outgrew the controls. Thus, by $72 \mathrm{~h}$ of incubation with 5-CT larval length was equal to that of the controls corresponding to $84 \mathrm{~h}$ of incubation (Figure 2A, B). The 5-CT-mediated acceleration of developmental rate started after $36 \mathrm{~h}$ of incubation and was persistent during the whole development (Figure 2A).

As a consequence of these receptor-mediated changes in the developmental rate, after $84 \mathrm{~h}$ of incubation (when control animals reached the middle of metamorphosis) the animals treated with RS67333 or 8-OH-DPAT were at premetamorphic stages only, while the animals treated with 5-CT already reached the end of metamorphosis
(Figure 2B). To compare the speed of development, the linear fitting was applied to the measurements of embryonic lengths and the slope was calculated (Figure 2A). This analysis provided slope coefficients $\mathrm{k}_{5-\mathrm{CT}}=7.5 \times 10^{-2}$ $\left(\mathrm{R}^{2}=0.992\right)>\mathrm{k}_{\text {control }}=6.8 \times 10^{-2}\left(\mathrm{R}^{2}=0.994\right)>\mathrm{k}_{8 \text {-OH-DPAT }}=$ $5.2 \times 10^{-2}\left(R^{2}=0.988\right)>k_{R S 67333}=3.1 \times 10^{-2}\left(R^{2}=0.976\right)$, where the higher value of the slope indicates the faster development.

Analysis of the specific set of morphological characters confirmed that differences in larval length correspond to different developmental stages. When control animals reached the middle of metamorphosis, the larvae exposed to RS67333 and 8-OH-DPAT (84 h of incubation) reached only the premetamorphic veliger stages. The control animals reached the stage 26: the shell covered the visceral mass; the foot, head tentacles and lung lobe developed, the eyes (though not yet pigmented) appeared at the base of the tentacles. The embryo attached the foot to the inner 
surface of the egg capsule and started to creep along it (gliding locomotion), though sometimes detached and continued rotational swimming. Additional movie files show this in more detail [see Additional file 1 and Additional file 2].

At the same time, the larvae exposed to RS67333 reached only the premetamorphic stage of early veliger (stage 22-23). They had a small foot, developing shell covered only the posterior half of the visceral mass, the tentacle rudiments and eyes just appeared. The larvae treated with 8-OH-DPAT also demonstrated developmental retardation, though not that profound (stage 24). They had an elongated foot distinctly separated from the head region, and the shell, which covered two-thirds of the visceral mass. In addition, the specimens treated with RS67333 and 8-OH-DPAT expressed only rotational swimming, which is characteristic for premetamorphic larvae (Figure 2B). For more detail see an additional movie file [see Additional file 3].

On the contrary, the animals treated with 5-CT were at the end of metamorphosis (stage 27) and looked like miniature adult snails (Figure 2B): the shell covered the whole visceral mass, and animals could withdraw their bodies into the shell, the eyes at the base of the head tentacles were pigmented and the lung lobe was elongated. These specimens showed no rotational swimming and crept along the inner surface of the egg capsule using the fully developed foot (Figure 2B). For more detail see an additional movie file [see Additional file 4]. No asynchrony in morphogenesis or disproportionality in growth of either inner (heart, larval liver, lung cavity, radular pouch) or outer organs (shell, lung lobe, foot, tentacles, eyes) was observed in all treated animals.

\section{Functional effects of 5-HTRs activation depend on the developmental stage}

To test whether the effects of 5-HTRs activation depend upon developmental stages of larvae, we incubated the specimens with specific receptor agonists starting either from the early premetamorphic trochophore stage 19 or from the middle veliger stage, just before metamorphosis (stage 23) and finishing the treatment when metamorphosis was complete (stage 28; Figure 2C). For each developmental stage, a separate experiment with a control and a batch exposed to the respective agonist was performed. When treatment with the $5-\mathrm{HT}_{4} \mathrm{R}$ agonist RS67333 started at the stage 19 , it resulted in significantly prolonged duration of development from the stage 19 until the stage 28 as compared to the controls $(167 \pm 14.3 \%$; $n=60, p<0.05$; Figure $2 \mathrm{C}$ ). The effect was less pronounced when treatment started from the stage $23(140 \pm 5.6 \% ; \mathrm{n}=40, p<0.05$, Figure $2 \mathrm{C}$ ). Incubation with $8-\mathrm{OH}-\mathrm{DPAT}$ also resulted in prolongation of development until the stage 28 , although the effect was weaker and stage-independent
(123 $\pm 19.1 \%$ at stage 19 ; and $135 \pm 5.6 \%$ at stage $23 ; \mathrm{n}=60$, $p<0.05$; Figure 2C). The effect of incubation with 5-CT was opposite - the time of development from stage 19 until stage 28 was significantly shorter as compared to the controls. The effect of 5-CT was more pronounced, when treatment started at the stage 23 than at the stage 19 $(90 \pm 9 \%$ at the stage 19 ; and $72 \pm 11.9 \%$ at the stage 23 ; $\mathrm{n}=60, p<0.05$; Figure $2 \mathrm{C}$ ).

\section{Pharmacological analysis of 5-HTRs involved in developmental retardation and acceleration}

We next analysed the dose-dependence of different agonists on the $H$. trivolvis developmental rate. As shown in Figure 3A, application of RS67333 at $5 \mu \mathrm{M}$ concentration completely blocked development and caused $100 \%$ mortality after $84 \mathrm{~h}$ of incubation $(\mathrm{n}=60)$. Application of $2.5 \mu \mathrm{M}$ and $1 \mu \mathrm{M}$ of RS67333 resulted in progressive retardation being more pronounced for the higher concentration $(\mathrm{n}=60, p<0.001$; Figure $3 \mathrm{~A})$. Treatment with different concentrations of 8-OH-DPAT resulted in similar effects: $10 \mu \mathrm{M}$ caused $10 \%$ mortality and the most pronounced retardation effect, $5 \mu \mathrm{M}$ and $2.5 \mu \mathrm{M}$ resulted in gradual retardation, where the higher concentration was more effective ( $\mathrm{n}=60, p<0.001$; Figure 3B). Treatment with 5-CT induced developmental acceleration in all tested concentrations with the maximal effect observed at the third day of incubation $(\mathrm{n}=60, p<0.001$; Figure 3C). Based on this data, the following drugs concentrations were selected for further pharmacological analysis: $2.5 \mu \mathrm{M}$ of RS67333, $5 \mu \mathrm{M}$ of 8-OH-DPAT and $1 \mu \mathrm{M}$ of 5-CT.

Subsequently, we analysed the rate of development, which was expressed as larval size measured after $84 \mathrm{~h}$ of incubation with different combinations of 5-HTR agonists and antagonists. Combined application of RS67333 and 8-OH-DPAT induced stronger inhibitory effects on the embryonic development (58 $\pm 7.4 \%)$ than separate applications of each agonist ( $63 \pm 8.9 \%$ and $83 \pm 5.1 \%$ respectively, $p<0.001$; Figure 3D). Developmental retardation caused by RS67333 was partially rescued by co-incubation with 5-CT (72 $\pm 8.5 \%, p<0.001$; Figure 3D).

We also tested whether the developmental effects obtained after application of different 5-HTR agonists were receptor specific. This is particularly important in case of 5-CT and 8-OH-DPAT, because these substances are known to be partial agonists for both $5-\mathrm{HT}_{7} \mathrm{R}$ and $5-\mathrm{HT}_{1} \mathrm{R}$, respectively [56,57]. Developmental retardation induced by RS67333 appeared to be indeed $5-\mathrm{HT}_{4} \mathrm{R}$-specific, since it was rescued by the specific receptor antagonist GR113808 (63 $\pm 8.9 \%$ for RS67333 alone vs. to $83 \pm 6 \%$ for RS67333 + GR113808; Figure 3D). Developmental acceleration induced by 5 -CT treatment was not affected by the $5-\mathrm{HT}_{7} \mathrm{R}$ antagonist SB269970 (Figure 3D), however, it was completely abolished after co-application of highly selective $5-\mathrm{HT}_{1} \mathrm{R}$ antagonist (S)-WAY100135 (110 $\pm 4.4 \%$ 

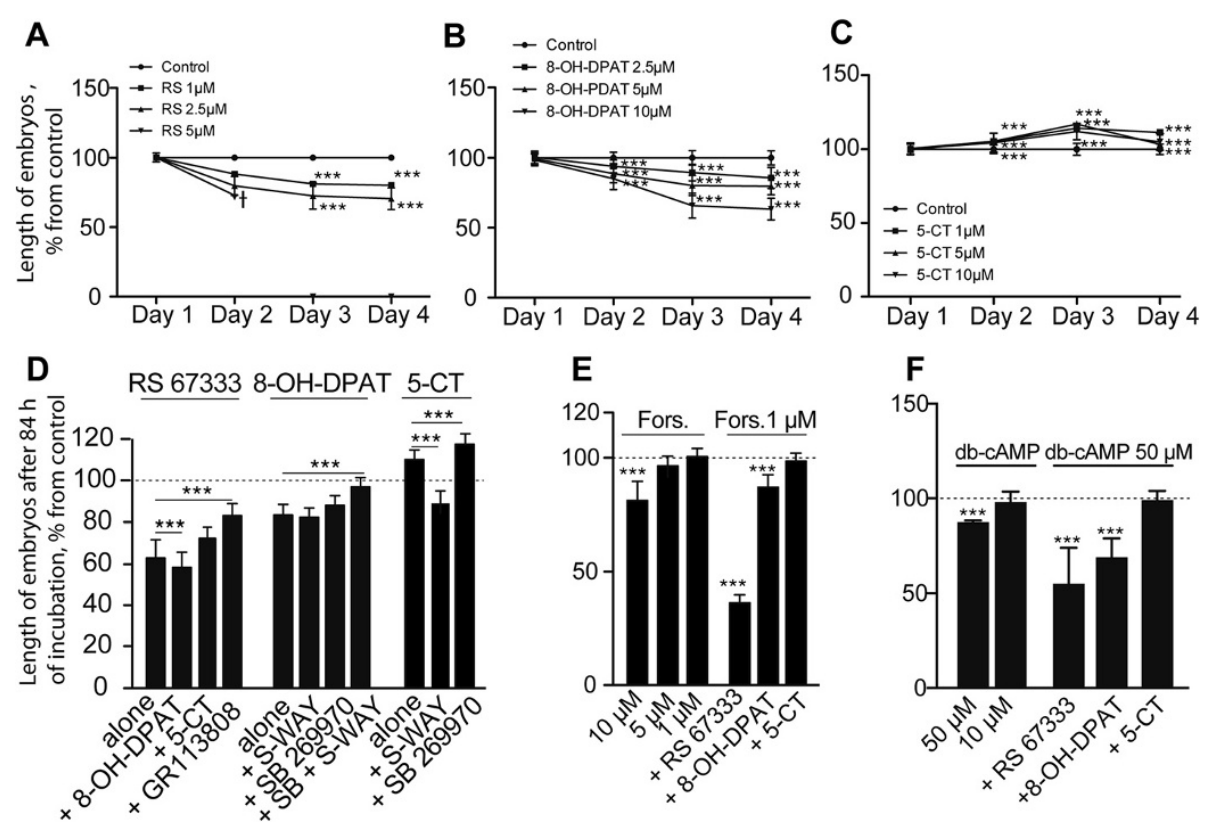

Figure 3 Pharmacological analysis of 5 -HT receptors involved in retardation and acceleration of $H$. trivolvis development. (A-C). Development tempo expressed as changes in the length of embryos is modulated upon treatment with different 5-HTR agonists in a dose-dependent manner. Treatment with RS67333 (A) and 8-OH-DPAT (B) results in retardation, while treatment with 5-CT (C) - in acceleration effects. (D) Effect of combined application of agonists and antagonists on the embryos length after $84 \mathrm{~h}$ of incubation. Data were normalized to the control and shown as mean \pm s.d. ( $(* * *, p<0.001)$. (E) Effect of forskolin treatment on the embryos length after $84 \mathrm{~h}$ of incubation. Normalized values represent means \pm s.d.; $\left.{ }^{* * *}, p<0.001\right)$. (F) Effect of db-cAMP treatment on the embryos length after $84 \mathrm{~h}$ of incubation. Normalized values represent means \pm s.d.; $(* * *, p<0.001)$.

for 5 -CT alone vs. $89 \pm 5.8 \%$ for 5 -CT in combination with (S)-WAY100135, $p<0.001$; Figure 3D). This is in line with previous findings demonstrating that 5 -CT displays much higher affinity for the 5- $\mathrm{HT}_{1} \mathrm{R}$ than 8-OH-DPAT [24].

The inhibitory effect of 8-OH-DPAT on the embryonic development was unaltered after co-treatment of larvae with $5-\mathrm{HT}_{7} \mathrm{R}$ antagonist $\mathrm{SB} 269970$ or $5-\mathrm{HT}_{1} \mathrm{R}$ antagonist (S)-WAY100135. However, combined application of these antagonists resulted in significant reduction of $8-\mathrm{OH}-$ DPAT-mediated developmental retardation to $97 \pm 4.3 \%$ (Figure 3D). These data suggest that developmental retardation induced by $8-\mathrm{OH}-\mathrm{DPAT}$ is most likely mediated via activation of $5-\mathrm{HT}_{7} \mathrm{R}$, although its pharmacological properties seems to differ from its mammalian counterpart.

Our pharmacological results demonstrate that activation of different serotonin receptors changed the developmental tempo of freshwater snail $\mathrm{H}$. trivolvis in alternative ways. While activation of $5-\mathrm{HT}_{4}$ - and $5-\mathrm{HT}_{7} \mathrm{Rs}$ caused retardation of development, stimulation of $5-\mathrm{HT}_{1} \mathrm{R}$ resulted in developmental acceleration.

\section{Developmental effects of 5-HTRs involve cAMP-mediated signalling}

The results of pharmacological analysis suggest that 5$\mathrm{HT}_{1^{-}}, 5-\mathrm{HT}_{4^{-}}$and $5 \mathrm{HT}_{7} \mathrm{Rs}$ are involved in regulation of development in $H$. trivolvis (Figures 2, 3). It has been suggested that invertebrate $G$ protein-coupled receptors might activate similar signalling pathways as their vertebrate homologues. In particular, activation of invertebrate $5-\mathrm{HT}_{1} \mathrm{Rs}$ results in $\mathrm{G}_{\mathrm{i}}$ protein-mediated inactivation of adenylyl cyclases (AC) and decrease of cAMP level [58]. Likewise, both vertebrate and invertebrate $5-\mathrm{HT}_{4}$ - and $5-\mathrm{HT}_{7} \mathrm{Rs}$ have been shown to be coupled to stimulatory $\mathrm{G}_{\mathrm{s}}$ proteins, leading to $\mathrm{AC}$ activation and increased cAMP production [59-61].

To test whether cAMP-mediated signalling is involved in regulation of $H$. trivolvis larval development, the specimens were treated with forskolin, a common substance used to increase the intracellular levels of cAMP by activation of AC [62-64]. Application of $10 \mu \mathrm{M}$ forskolin induced retardation of development to $82 \pm 5.8 \%$ as compared to the control after $84 \mathrm{~h}$ of incubation $(\mathrm{n}=100, p<0.001$; Figure $3 \mathrm{E})$, while the lower concentrations $(5 \mu \mathrm{M}$ and $1 \mu \mathrm{M})$ of forskolin had no effect on embryonic development ( $96 \pm 4.3 \%$ and $101 \pm 3.4 \%$ respectively, $n=100$; Figure 3E). However, combined treatment of embryos with low concentration of forskolin $(1 \mu \mathrm{M})$ and RS67333 (5- $\mathrm{HT}_{4} \mathrm{R}$ agonist) resulted in stronger retardation effect of RS67333 compared to the same concentration of RS67333 alone: $36 \pm 8 \%$ vs. $63 \pm 8.9 \%$, $(\mathrm{n}=100, p<0.001)$. Moreover, low concentration of forskolin significantly reduced 
accelerative effect of 5-CT (5- $\mathrm{HT}_{1} \mathrm{R}$ agonist) from $110 \pm$ $4.4 \%$ to $99 \pm 2.8 \%(\mathrm{n}=100$; Figure $3 \mathrm{E})$.

Incubation of embryos with db-cAMP, cell permeable analogue of cAMP, confirmed the role of cAMP in developmental regulation. After $84 \mathrm{~h}$ of incubation, $50 \mu \mathrm{M}$ db-cAMP induced retardation of development to $89 \pm 9.7 \%$ as compared to the control $(\mathrm{n}=56, p<0.001$; Figure 3F), while incubation in $10 \mu \mathrm{M}$ had no effect $(98 \pm 5.4 \%, \mathrm{n}=60$; Figure 3F). Combined treatment of embryos with $50 \mu \mathrm{M}$ $\mathrm{db}$-cAMP and RS67333 resulted in stronger retardation effect of RS67333 compared to the same concentration of RS67333 alone: $56 \pm 19.5 \%$ vs. $63 \pm 17.2 \%, \quad(n=42$, $p<0.005)$. Stronger retardation was also obtained after combined application of $50 \mu \mathrm{M} \mathrm{db}$-cAMP and 8-OH-DPAT compared to the same concentration of 8-OH-DPAT alone: $69 \pm 10.4 \%$ vs. $78 \pm 11.8 \%$, ( $\mathrm{n}=54, p<0.005)$. Moreover, addition of db-cAMP reduced accelerative effect of 5-CT from $107 \pm 3.8 \%$ to $99 \pm 4.9 \%(\mathrm{n}=45$; Figure $3 \mathrm{~F})$.

It is noteworthy that inhibition of both adenylate cyclase and phosphodiesterase by MDL 12330A resulted in 100\% death after $24 \mathrm{~h}(50 \mu \mathrm{M}, \mathrm{n}=68)$ or $48 \mathrm{~h}(10 \mu \mathrm{M}, \mathrm{n}=72)$ of incubation. Low concentration of MDL 12330A (5 $\mu \mathrm{M})$ resulted in $50 \%$ death within three days. Protein kinase A inhibitor $\mathrm{H} 89$ induced $100 \%$ death after $24 \mathrm{~h}$ of incubation in $10 \mu \mathrm{M}$ and $20 \mu \mathrm{M}$ concentrations, while incubation in $1 \mu \mathrm{M} \mathrm{H} 89$ resulted in non-significant acceleration of development and considerably increased dispersion between length of embryos inside the treated groups $(104 \pm 12.3 \%, \mathrm{n}=51, p=0.057)$.

To verify the role of stimulatory $\mathrm{G}_{\mathrm{s}}$ protein (a downstream effector of both $5-\mathrm{HT}_{4} \mathrm{R}$ and $5-\mathrm{HT}_{7} \mathrm{R}$ ) in developmental retardation we applied the fluorescence-based GTP $\gamma \mathrm{S}$ assay performed on the membrane preparations (Figure 4A). Specific coupling of 5-HTR to respective G protein was analyzed by immunoprecipitation (IP) with anti- $\mathrm{G}_{\mathrm{s}}$ and anti- $\mathrm{G}_{\mathrm{q}}$ antibodies raised against corresponding $\mathrm{G}$ proteins of human origin. 5-HT induced approximately 3 -fold increase in $(\mathrm{Eu}) \mathrm{GTP} \gamma \mathrm{S}$ binding to the $\mathrm{G}_{\mathrm{s}}$-protein and did not induce increase in $(\mathrm{Eu}) \mathrm{GTP} \gamma \mathrm{S}$ binding to the $\mathrm{G}_{\mathrm{q}}$ protein. Moreover, FMRFamide, a peptide known to stimulate $G_{q}$ protein-linked $\mathrm{IP}_{3}$ pathway in fresh-water mollusc [65] induced about 2,5 folds increase in (Eu) GTP $\gamma$ S binding to the $\mathrm{G}_{\mathrm{q}}$-protein (Figure 4A). Taken together, pharmacological analysis and GTP $\mathrm{S}$ binding assay demonstrate that $\mathrm{G}$ protein-mediated cAMP signalling pathway dominates in 5-HTR mediated modulation of developmental tempo in $H$. trivolvis larvae, and the increase of intracellular cAMP level results in developmental retardation.

Expression patterns of 5-HTRs and related G proteins are different at premetamorphic and metamorphic stages Pharmacological experiments have demonstrated that the effects of 5-HTRs activation depend on the developmental stage (Figure 2C). One possible explanation for these effects might be the variation in expression patterns of 5-HTRs and/or corresponding G proteins. Therefore, we exploited quantitative real-time PCR to compare the relative expression levels of the mRNA that eventually gives rise to $5 \mathrm{HT}$ receptors at different stages of development. Since both $5-\mathrm{HT}_{1}$ - and $5-\mathrm{HT}_{7} \mathrm{Rs}$ have been recently cloned from the genome of $H$. trivolvis [30], it was possible to create specific PCR primers to study their relative expression.

The expression profiles for $5-\mathrm{HT}_{1} \mathrm{R}$ and $5-\mathrm{HT}_{7} \mathrm{R}$ were analysed at three stages: (i) stage 19 long before metamorphosis, (ii) stage 23 shortly before metamorphosis and (iii) stage 25 that corresponds to the beginning of metamorphosis. The analysis revealed strong transient increase of $5-\mathrm{HT}_{1} \mathrm{R}$ expressions at the stage 23 , while at the earlier and later stages 19 and 25 its expression was significantly lower (up to threefold; Figure 5A). In contrast, expression level of $5-\mathrm{HT}_{7} \mathrm{R}$ was higher at the premetamorphic stages 19 and 23, and down regulated at metamorphic stage 25 (Figure 5B).

To monitor whether the changes in mRNA level reflect differences in the expression level of corresponding proteins, we performed a quantitative Western blot analysis. Since antibodies against $H$. trivolvis 5-HTRs are not commercially available, we tested antibodies against $5-\mathrm{HT}_{1 \mathrm{~A}}$, $5-\mathrm{HT}_{4}$ and $5-\mathrm{HT}_{7} \mathrm{Rs}$ of human and murine origin. Application of three different commercially available antibodies against $5-\mathrm{HT}_{4-}$ and $5-\mathrm{HT}_{7} \mathrm{Rs}$ produced no specific signal (data not shown). In contrast, application of the antibody directed against human $5-\mathrm{HT}_{1 \mathrm{~A}} \mathrm{R}$ resulted in clearly detectable protein band with a molecular weight of around $48 \mathrm{kDa}$ that corresponded to the expected molecular weight of the $5-\mathrm{HT}_{1} \mathrm{R}$ (Figure 4B). This antibody was therefore used for the quantitative analysis of the 5$\mathrm{HT}_{1} \mathrm{R}$ expressions at different developmental stages of H. trivolvis.

As shown in Figure 4C, the relative amount of the $5-\mathrm{HT}_{1} \mathrm{R}$ was significantly higher $(119 \pm 13 \%)$ at the stage 23 than at the stage $19(7.9 \pm 4 \%)$ and $25(34.3 \pm 7 \%)$. Similar expression profile was obtained for the $G_{i}$ protein, the main coupling partner of the $5-\mathrm{HT}_{1} \mathrm{R}(5.7 \pm 2 \%$ at the stage $19,38.6 \pm 8 \%$ at stage 23 and $10.9 \pm 3 \%$ at the stage 25; Figure 4D). The $G_{s}$ protein that is coupled to both $5-\mathrm{HT}_{4}$ - and $5-\mathrm{HT}_{7} \mathrm{Rs}$, was strongly expressed during the early premetamorphic developmental stage (stage 19) and gradually down-regulated (up to 5-folds) by the metamorphic stage $(95.8 \pm 5 \%$ at the stage $19,49.8 \pm 10.7 \%$ at the stage 23 and $21.2 \pm 8 \%$ at the stage 25; Figure $4 \mathrm{E}$ ). These results confirm real-time PCR data (Figure 5B) and strongly suggest that coordinated expression of the receptors and related $\mathrm{G}$ proteins might represent a mechanism responsible for the alternative effects of 5-HT at premetamorphic and metamorphic stages of $H$. trivolvis development. 

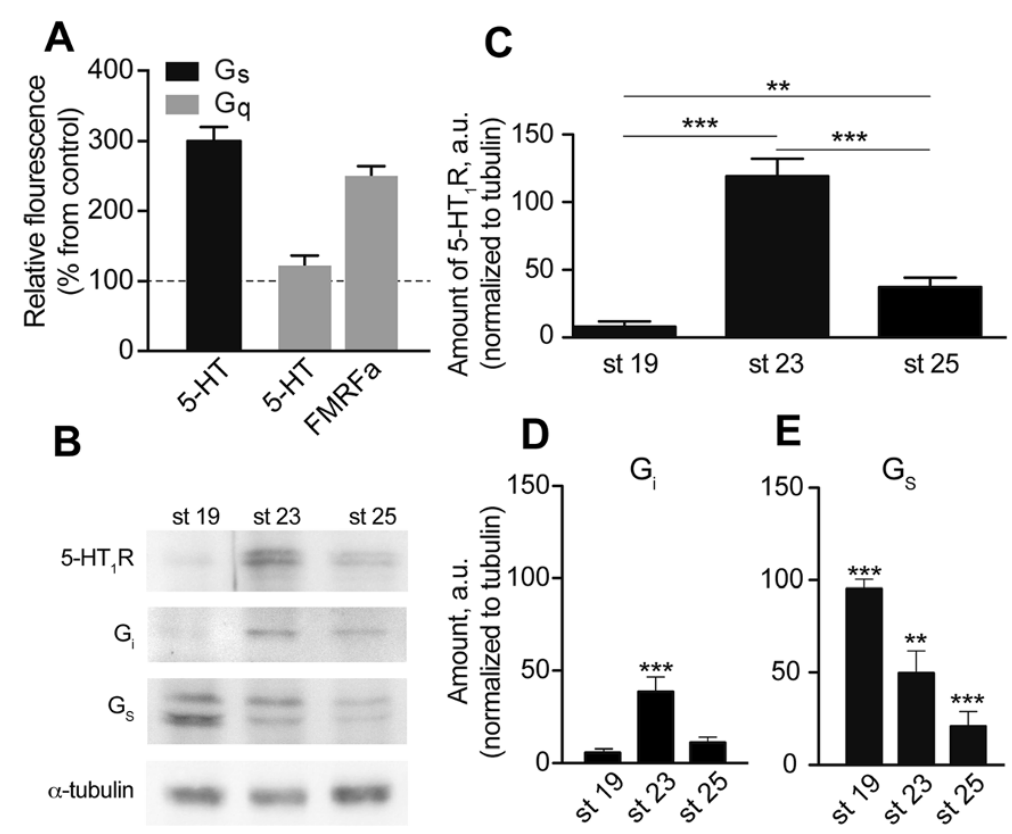

Figure 4 Expression and activation of $\mathrm{G}$ proteins and $\mathbf{5}-\mathrm{HT}_{\mathbf{1}}$ receptor during $\boldsymbol{H}$. trivolvis development. (A) (Eu)GTPyS binding assay demonstrates 5 -HT-iduced activation of $G_{s}$, but not $G_{q}$ protein in membrane preparations of $H$. trivolvis. Activation of $G_{q}$ by FMRFamide was used as a positive control. (B) Western blot representing proteins from membrane preparations of H. trivolvis embryos at different developmental stages. The

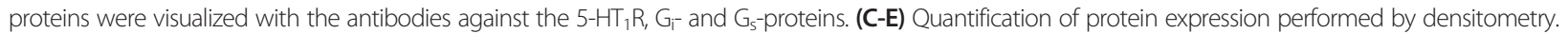
Relative amounts of 5-HT $R(\mathbf{C}), G_{i}-$ protein $(\mathbf{D})$, and $\mathrm{G}_{\mathrm{s}}$-protein $(\mathbf{E})$ are shown at the stages 19, 23, and 25. Expression of 5-HT, receptor and $\mathrm{G}$ proteins undergoes changes during $\mathrm{H}$. trivolvis development. Maximal expression of $5-\mathrm{HT}_{1} \mathrm{R}$ and corresponding $\mathrm{G}_{\mathrm{i}}$-protein was obtained at the beginning of metamorphosis (st 23), while $G_{s}$-protein was maximally expressed at the premetamorphic stage (st 19) and gradually decreases by the metamorphic stage (st 25). Each value represents the mean \pm s.d. $(n=4)$. A statistically significant difference between values is noted $\left(* *, p<0.01, *^{* *}, p<0.001\right)$.

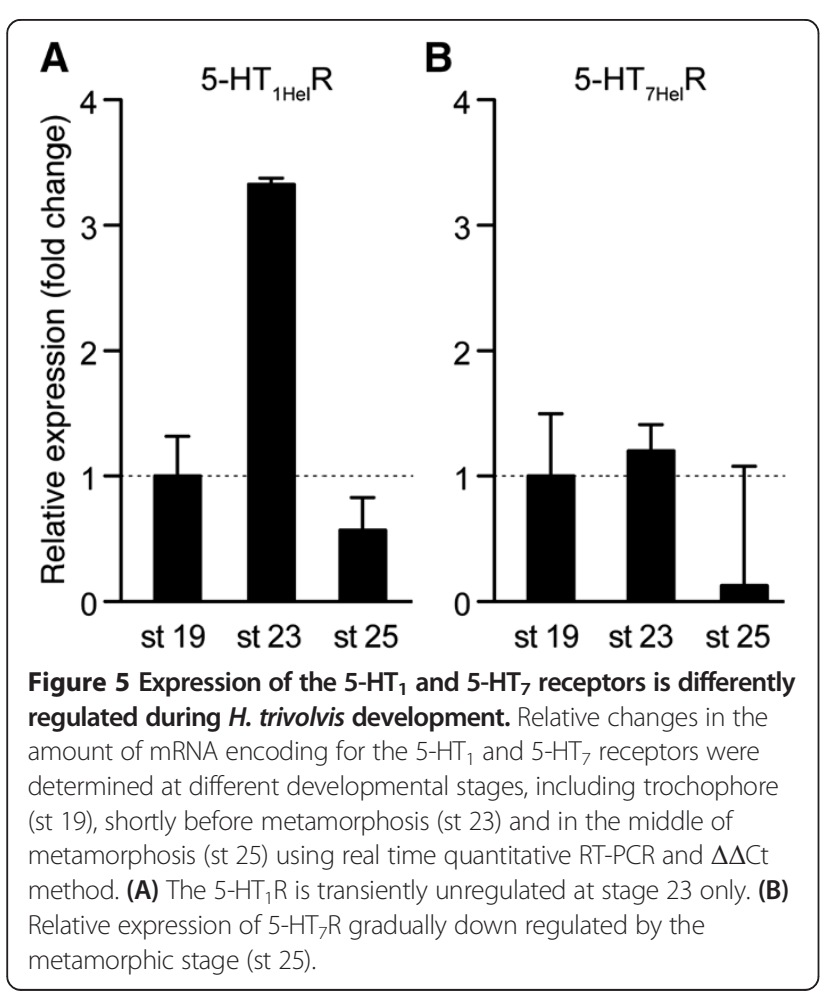

Activation of 5 -HTRs regulates cell proliferation rate of Helisoma trivolvis larvae in a stage-dependent manner The above analysis of 5-HTRs and corresponding G proteins indicates that cAMP is critically involved in regulation of the developmental tempo. Cyclic AMP is known to be one of the regulators of cell division rates [66-71] suggesting that agonist induced changes in the $H$. trivolvis developmental rate might correspond to the changes in cell division rates. To test it, we studied the effects of different 5-HTR agonists on the number of dividing cells at the developmental stages 19, 23 and 25. Incubation with different agonists was followed by the staining with the antibody against the phosphorylated form of $\mathrm{H} 3$ histone, which binds to the histone molecules only at the prophase and metaphase stages of mitosis [72-74], and thus allows visualization of dividing cells (Figure 6A).

Treatment of animals with $5-\mathrm{HT}_{4} \mathrm{R}$ agonist RS67333 $(5 \mu \mathrm{M})$ at premetamorphic stages 19 and 23 significantly inhibited cell divisions to $2.5 \pm 5.6 \%$ and $33 \pm 16.4 \%$ respectively (Figure 6A, B, $\mathrm{n}=10, p<0.0001$ and $p<0.001$ respectively). Treatment at the metamorphic stage 25 had no significant influence on the number of dividing cells $(114 \pm 33.1 \%, \mathrm{n}=10 ; p>0.05$; Figure 6A, B). Incubation of animals with $5-\mathrm{HT}_{7} \mathrm{R}$ agonist 8-OH-DPAT $(5 \mu \mathrm{M})$ at the stage 19 resulted in significant reduction in the number of 


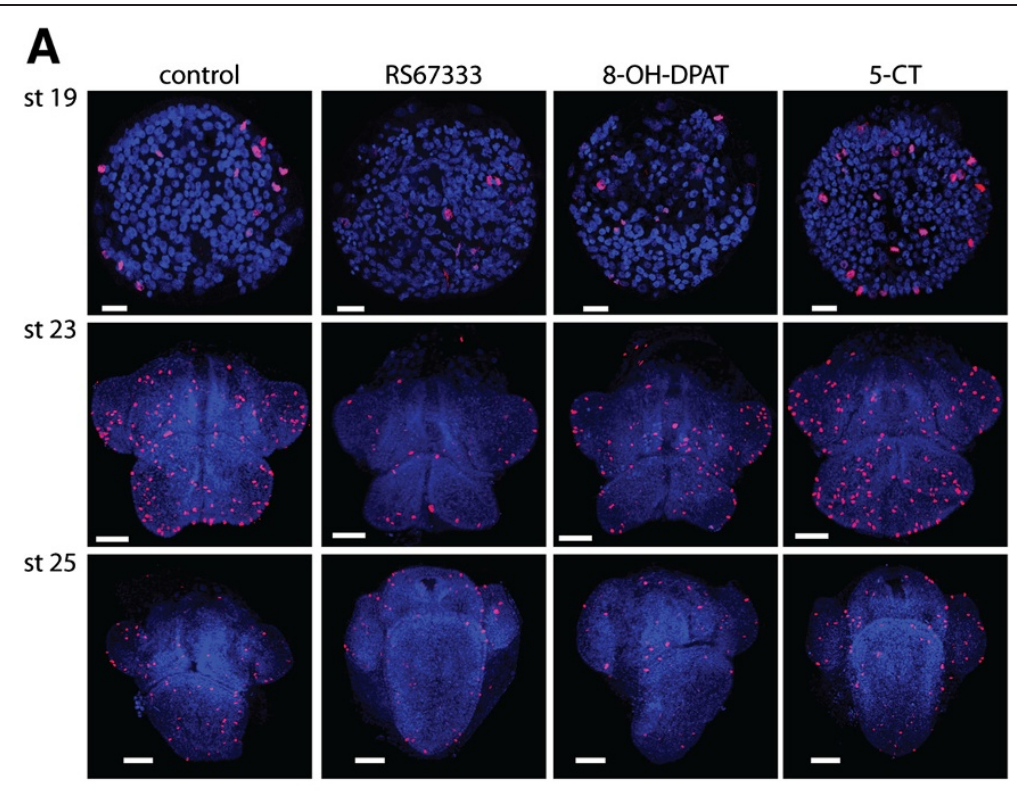

B

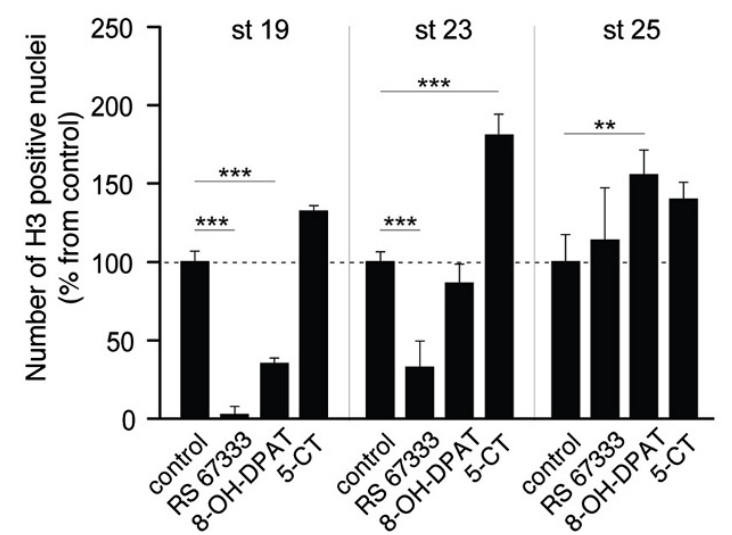

Figure 6 Effects of different 5 -HT receptor agonists on cell proliferation during $\boldsymbol{H}$. trivolvis development. (A) Representative confocal images of the whole-mount $\mathrm{H}$. trivolvis embryos co-stained with DAPI (blue) and the antibody against phospho-H3S28 (red) after incubation with RS67333, 8-OH-DPAT and 5-CT (5 $\mu$ M each). Staining with anti-phospho-H3S28 antibody allows visualization of dividing cells. Scale bars are $20 \mu \mathrm{M}$ for the stage 19, and $50 \mu \mathrm{M}$ for the stages 23 and 25. (B) The relative number of dividing cells at stages 19, 23 and 25 after $10 \mathrm{~h}$ of incubation with RS67333, 8-OH-DPAT and 5-CT. Each value represents the mean \pm s.e.m. $(n=10)$. A statistically significant difference between values is noted (** $p<0.01$, *** $p<0.001)$.

mitotic cells to $35 \pm 12.3 \%$ (Figure $6 \mathrm{~A}, \mathrm{~B}, \mathrm{n}=10$; $p<0.001$ ). However, this inhibitory effect was weaker at the stage 23 $(86 \pm 36.5 \%, \mathrm{n}=10 ; p>0.05)$ and even reversed to induce stimulation of cell divisions at the stage 25 (156 $\pm 49.2 \%$, $\mathrm{n}=11 ; p<0.01$; Figure 6$)$. On the contrary, incubation of embryos with $5-\mathrm{HT}_{1} \mathrm{R}$ agonist 5 -CT resulted in a strong increase in the number of mitotic cells at stage 23 (133 \pm $35.2 \%$ at the stage $19, \mathrm{n}=10, p>0.05 ; 181 \pm 40.5 \%$ at the stage $23, \mathrm{n}=10, p<0.001$ and $139 \pm 36.2 \%$ at the stage 25 , $\mathrm{n}=11, p>0.05$; Figure $6 \mathrm{~A}, \mathrm{~B}$ ) when expression of $5-\mathrm{HT}_{1} \mathrm{R}$ and $G_{i}$ protein reached the maximum values (Figures $5 \mathrm{~A}$, $4 C, D)$. Thus, at premetamorphic stages, the retarding effects of RS67333 and 8-OH-DPAT are at least partly based on receptor-mediated suppression of cell divisions, and the accelerating effect of 5-CT is based on receptormediated increase of cell divisions.

\section{Discussion}

Development of $H$. trivolvis larvae includes transition from premetamorphic to metamorphic stages

Freshwater gastropod snails develop from the first cleavage to the juvenile stage entirely within egg capsules. Thus, unlike the majority of other mollusks, $H$. trivolvis does not have free-swimming larval stages $[75,76]$. However, sufficient vestiges of larval phases and similarities in timing of the appearances of various other structures exist such 
that parallels with developmental processes in marine gastropods can nonetheless still be inferred [77]. It has been demonstrated that $H$. trivolvis possesses specialized larval characters such as the apical 5-HT-immunoreactive neurons belonging to the ASO $[28,78,79]$. We demonstrate that these ASO neurons as well as dorsolateral and pedal ciliary bands are transient structures, suggesting that they are homologous to the respective structures of molluscan free-swimming larvae $[1,80,81]$. It has been postulated that all metamorphoses share four main components: (1) the differentiation of juvenile/adult structures, (2) the degeneration of larval structures, (3) metamorphic competence, and (4) change in habitat [82]. Taken together, our morphological and behavioural data demonstrate that encapsulated larvae of $H$. trivolvis possess all these components and undergo the transition from the premetamorphic to metamorphic stage.

\section{5- $\mathrm{HT}_{1}-, 5-\mathrm{HT}_{4}-$ and $5-\mathrm{HT}_{7}$-like receptors are involved in regulation of Helisoma trivolvis development}

Several previous reports were focused on the effects of various neurotransmitters, such as 5-HT, GABA, acetylcholine, dopamine and histamine on metamorphosis of aquatic invertebrates [24,83-89]. It has been shown that in a broad range of species all these transmitters can modulate the processes of metamorphosis and settlement of competent larvae. Thus, 5 -HT was shown to trigger metamorphosis and induce settlement in hydroids, ascidians, barnacles and molluscs [21-26,30].

5-HT was detected in early larvae of molluscs long before the onset of metamorphosis $[2,41,42,44,77,78,90]$. We have shown that endogenous 5 -HT produced by the apical sensory neurons of larval $H$. trivolvis can either retard or accelerate the developmental tempo (the speed of transition from one stage to another) depending on the stage the larva passes $[35,36]$. Our data suggest that internal 5-HTRs are present from the early stages of larval development, and probably different sets of 5-HTRs are active at different developmental stages. Two receptors belonging to the 5 - $\mathrm{HT}$ family, $5-\mathrm{HT}_{1} \mathrm{R}$ and $5-\mathrm{HT}_{7} \mathrm{R}$, have been cloned for $H$. trivolvis [30], and involvement of both receptors in cilioexcitatory response to serotonin was suggested [29]. However, no experimental data about their functional role was yet provided.

In the present study, we utilized combination of pharmacological, biochemical and molecular approaches for characterisation of $H$. trivolvis 5-HTRs involved in 5-HT-mediated changes in developmental tempo. The effects of commonly used agonists and antagonists for $5-\mathrm{HT}_{1^{-}}, 5-\mathrm{HT}_{4^{-}}$and $5-\mathrm{HT}_{7} \mathrm{Rs}$ obtained in our experiments strongly suggest that receptors of these subfamilies are functionally active in $H$. trivolvis larvae. It is supported by the following observations: (i) All used agonists demonstrated their functional effects in low $(\mu \mathrm{M})$ concentrations and in dose-dependent manner. (ii) If applied simultaneously, different agonists demonstrated expected summation of their effects: RS67333 and 8-OH-DPAT showed additive action, and RS67333 and 5-CT decreased the effects of each other. (iii) Agonist-mediated effects were attenuated by the application of corresponding antagonists.

It is possible that changes in the developmental tempo observed in experimental animals may result from heterochrony rather than developmental retardation or acceleration. However, we are quite confident in that heterochrony can be neglected by several reasons. First, we always checked the dispersion in developmental stages between individual animals within experimental and control groups by inspecting the set of morphological, morphometric and behavioural characters. Second, we always measured the dispersion in the length of embryos. One of characteristic features of $H$. trivolvis that makes this animal a suitable experimental model is highly synchronous embryonic development with low divergence between individual embryos within one egg mass (see Table 1), and this divergence in experimental groups never significantly differed from the controls. Moreover, any disproportionality in growth and malformations were never observed in experimental animals.

PCR and Western Blot analysis confirmed the presence of $5-\mathrm{HT}_{1}$ and $5-\mathrm{HT}_{7}$ receptors at all examined developmental stages. The presence of $5-\mathrm{HT}_{4}$ like receptor was suggested based on the response to specific drugs. Although invertebrate receptors can have different affinity for drugs if compared to the vertebrate ones, our data suggest that $H$. trivolvis receptor indeed belongs to the $5-\mathrm{HT}_{4}$ subfamily. First, action of the corresponding agonist RS67333 was strictly concentration-dependent; it was rescued by the specific antagonist (GR113808) and was not rescued by other antagonists. Second, this receptor is coupled to the cAMP signalling pathway since the effect of RS67333 significantly increased after co-application with db-cAMP and forskolin though low concentrations of db-cAMP and forskolin alone were non-effective.

Pharmacological analysis shows that inhibitory action on developmental tempo of pharmacological agents that mimic the effects of endogenous 5 - $\mathrm{HT}$ is mediated via activation of $5-\mathrm{HT}_{7}-$ and $5-\mathrm{HT}_{4} \mathrm{Rs}$, whereas accelerating action is mediated through the activation of $5-\mathrm{HT}_{1} \mathrm{R}$. It is known that 5 -HT or some 5-HTRs agonists stimulate rotation of $H$. trivolvis embryos mixing the egg capsule fluid, thereby enhancing delivery of environmental oxygen to the embryo $[27,29]$. It might be suggested that changes in developmental tempo can be caused by increase or decrease in embryo rotation and thereby changes in larval metabolism. However, our previous work demonstrated that external 5-HT strongly stimulated embryonic rotations, while it did not influence the developmental rate [35]. Thus, only endogenous $5-\mathrm{HT}$ produced by the apical neurons in 
response to the external stimulus induces the changes in developmental tempo, whereas exogenous 5 - $\mathrm{HT}$ acts on the surface ciliary structures and stimulates rotations.

Our data demonstrate that the cAMP pathway is involved in regulation of developmental tempo, since elevation of the cAMP level by forskolin and application of db-cAMP resulted in developmental retardation. Coapplication of forskolin and db-cAMP enhanced the effects of 5-HT receptor agonists that are positively coupled to AC. Besides, our coupling assay, demonstrated 5-HTmediated activation of $\mathrm{G}_{\mathrm{s}}$ (cAPM pathway) but not $\mathrm{G}_{\mathrm{q}}$ ( $\mathrm{IP}_{3}$ pathway) protein. To the contrary, artificially raising the intracellular $\mathrm{Ca}^{2+}$ concentration caused a 5-HT-like increase in the cilia-driven rotational movements, while treatments that elevate the concentration of intracellular cAMP, did not mimic the 5-HT-induced increase in the ciliary beat frequency [91]. Thus, the two processes, stimulation of ciliary locomotion and modulation of developmental tempo possibly utilise different physiological mechanisms.

\section{5-HTRs modulate the cAMP-dependent regulation of cell divisions in Helisoma larvae}

$5-\mathrm{HT}_{1^{-}}, 5-\mathrm{HT}_{4}$ - and $5-\mathrm{HT}_{7} \mathrm{Rs}$ differ in their intracellular signalling in that $5-\mathrm{HT}_{1} \mathrm{R}$ inhibits the activity of AC via activation of inhibitory $\mathrm{G}_{\mathrm{i}}$ proteins, while $5-\mathrm{HT}_{4}$ - and 5$\mathrm{HT}_{7} \mathrm{Rs}$ stimulate $\mathrm{AC}$ via activation of stimulatory $\mathrm{G}_{\mathrm{s}}$ protein $[92,93]$. We demonstrate that both $G_{i}$ and $G_{s}$ proteins are present in $H$. trivolvis larvae and cAMP is involved in signal transduction pathway of 5-HT. This is directly confirmed by serotonin-induced (Eu)GTP $\gamma \mathrm{S}$ binding to the $\mathrm{G}_{\mathrm{s}}$-protein as well as by pharmacological analysis.

Importance of cAMP in development is well known. In the amoeba Dictyostelium discoideum, production of cAMP induced the transition from growth to development [94]. Elevation of cAMP in crayfish postponed molting and prolonged current life stages [95]. Increase of cAMP production by an external signal (natural or artificial) induced metamorphosis in competent larvae of gastropod mollusc Haliotis rufescens [84]. cAMP pathway mediates settlement of larvae in marine annelids $[63,64]$. Metamorphosis is mediated by a combination of both AC/CAMP and PI/ DAG/PKC pathways in larvae of the barnacle B. amphitrite [96-98]. Our observation that modulation of cAMP level through activation of 5-HT receptors influences the tempo of larval development in $H$. trivolvis is in agreement with the above listed data. How changes in the cAMP level can modulate the complex process of larval development, including cell divisions, growth and differentiation of tissues and organs? Our data demonstrate that at least the rate of cell divisions in $\mathrm{H}$. trivolvis is under control of 5HTRs. Activation of receptors which rise the cAMP level (5- $\mathrm{HT}_{4}-$ and $\left.5-\mathrm{HT}_{7} \mathrm{Rs}\right)$ resulted in reduced number of dividing cells, whereas activation of $5-\mathrm{HT}_{1} \mathrm{R}$, which decreased the cAMP level, increased the number of cell divisions. These results are in accordance with the data demonstrating that cAMP can regulate mitosis in various cell types by inhibition or even arrest of cell cycle progression [66-71]. Noteworthy, the reduction in cell divisions observed at premetamorphic stages correlates with the higher expression level of $\mathrm{G}_{\mathrm{s}}$ protein-coupled $5-\mathrm{HT}_{7} \mathrm{R}$. Also the pronounced increase of cell divisions obtained shortly before metamorphosis match well with the expression peak of $5-\mathrm{HT}_{1} \mathrm{R}$. Taken together these results suggest that cAMP might have a conservative function in regulation of cell cycle among broad variety of species.

\section{Coordinated expression of 5-HTRs and coupled G proteins can regulate transition of trochophore larvae from precompetent to competent stage}

Larvae that are able to undergo metamorphosis in response to specific cues are called "competent". Metamorphic competence was defined as "the developmental potential of a larva to undergo the radical transition from a larval to a juvenile/adult body plan in response to internal or external signals" [83]. Noteworthy, in one species, the duration of premetamorphic (precompetent) stage may vary from several days to several weeks $[17,99]$, and even from weeks to more than a year [100]. The question about basic differences between precompetent and competent larvae has been debated for a long time $[16,17,101]$. In the majority of aquatic animals, no specialized morphological structures, which are absolutely necessary for metamorphosis, appear in competent larvae. Only in few species among investigated, transition to larval competence is accompanied by appearance of specific morphological characters (i.e. propodium and red spots on the mantle of Aplysia) [16]. More often, no morphological correlates can be found, and the larva becomes competent when it starts to react to external signals that induce metamorphosis. The ASO and its serotonergic neurons have been experimentally proven to be required for detection of these signals and settlement initiation [49]. However, in all species investigated so far, the ASO appears long before metamorphosis and the larva does not react to the signals until it becomes competent $[16,25,39]$. Several recent studies have employed genomic, transcriptomic and proteomic approaches to elucidate mechanisms underlying the metamorphic competence and settlement. Although these studies have produced a large number of candidate mechanisms [16], they have not been confirmed by functional analysis.

Experimental data presented in our study suggest that transition from a latent, noncompetent state to an alert competent state (when the larva is ready to respond to metamorphic signals) can be provoked by changes in the expression level of particular serotonin receptors and respective $\mathrm{G}$ proteins. As a result of such regulated expression, the external signal that previously retarded 
the development or was meaningless starts to facilitate the development or triggers metamorphic events. Both processes can be initiated by activation of the same apical sensory neurons that release 5-HT. Based on our results, we propose a novel mechanism by which serotonergic neuroendocrine signalling can differentially regulate development of $\mathrm{H}$. trivolvis at precompetent and competent stages (Figure 7).

According to the proposed mechanism, premetamorphic and metamorphic larvae differ in the expression pattern of 5-HTRs and G proteins. At premetamorphic (precompetent) stages, expression of $5-\mathrm{HT}_{4}$ and $5-\mathrm{HT}_{7} \mathrm{Rs}$ and corresponding $\mathrm{G}_{\mathrm{s}}$ protein prevails while expression of $5-\mathrm{HT}_{1} \mathrm{Rs}$ and corresponding $\mathrm{G}_{\mathrm{i}}$ protein is low. In the
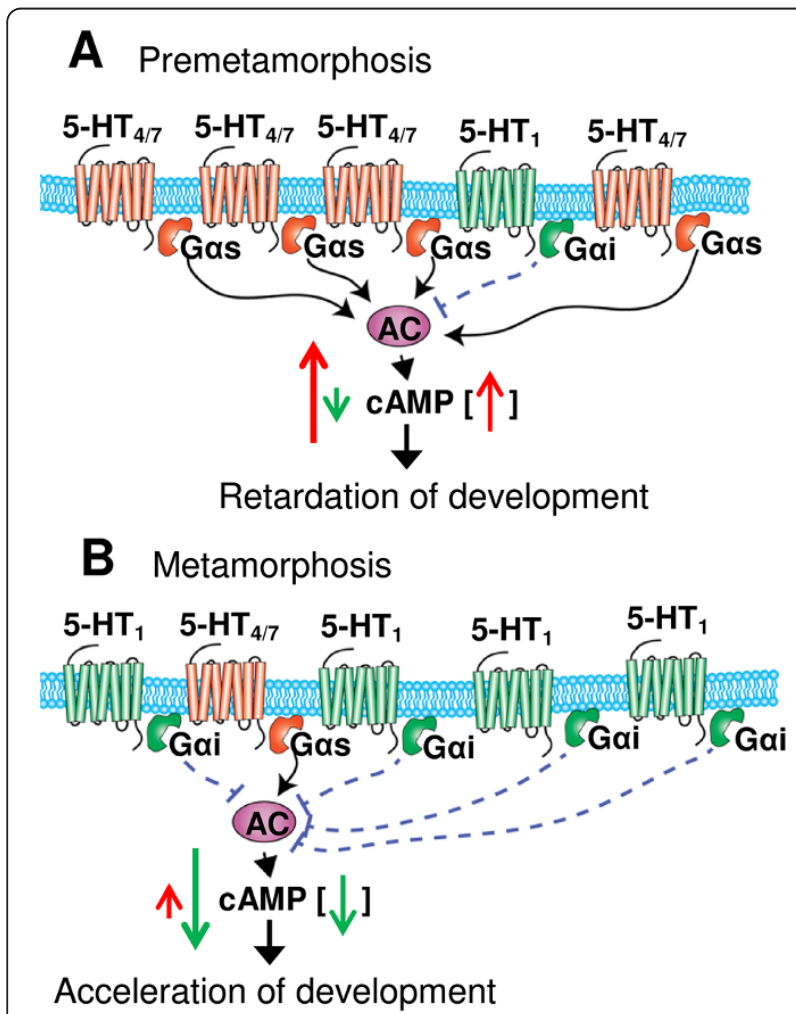

Figure 7 Proposed mechanism of stage dependent 5-HT receptor mediated regulation of larval development in $H$. trivolvis. (A) At premetamorphic stage, $\mathrm{G}_{\mathrm{s}}$-coupled serotonin receptors (such as $5-\mathrm{HT}_{4} \mathrm{R}$ and $5-H_{7} \mathrm{R}$ ) and their down-stream effectors are highly expressed and their relative amount exceeds that of $5-\mathrm{HT}_{1}$ receptor and coupled $\mathrm{G}_{\mathrm{i}}-$ protein. Thus, the ligand activation of different $5-H T$ receptor subtypes results in overall elevation of cAMP level (red arrow in square brackets), which leads to decreased rate of cell divisions and finally results in developmental retardation. (B) At metamorphic stage, $5-H_{4} \mathrm{R}, 5-\mathrm{HT} \mathrm{T}_{7} \mathrm{R}$, and coupled $\mathrm{G}_{\mathrm{s}}$-protein become down-regulated, while expression of $5-H T_{1} R$ and $\mathrm{G}_{1}$-protein increases. Relative amount of $5-H T_{1} R$ now exceeds that of $5-\mathrm{HT}_{4} \mathrm{R}$ and $5-\mathrm{HT}_{7} \mathrm{R}$, and ligand stimulation results in overall reduction of CAMP level (green arrow in square brackets), and subsequent developmental acceleration. According to the proposed mechanism, endogenous serotonin released from the ASO neurons in respond to external cues induces opposite effects at premetamorphic and metamorphic stages. course of development, $5-\mathrm{HT}_{1} \mathrm{Rs}$ and $\mathrm{G}_{\mathrm{i}}$ proteins undergo up-regulation and become preferential at metamorphic (competent) stage. Depending on what types of receptors (5- $\mathrm{HT}_{4}-$ and $5-\mathrm{HT}_{7} \mathrm{Rs}$ or $5-\mathrm{HT}_{1} \mathrm{Rs}$ ) and their downstream partners $\left(\mathrm{G}_{\mathrm{s}}-\right.$ or $\mathrm{G}_{\mathrm{i}}$-proteins) prevail at a particular developmental stage (premetamorphic or metamorphic), endogenous 5-HT released from serotonergic neurons of the ASO in response to external cues will either result in the increase of cAMP level and retardation via modulation of cell cycle progression at premetamorphic stage, or result in decrease of cAMP level and acceleration of the developmental tempo at metamorphic stage.

Besides serotonergic neurons, cells producing dopamine [54], histamine [89], as well as neurons containing nitric oxide synthase $[102,103]$ and peptides of the RFamide family [104-106] were found in the nervous system of invertebrate larvae, particularly in the ASO, and some of these neurotransmitter systems were shown to act in coordination during settlement and metamorphosis of free swimming invertebrate larvae $[82,89,107]$. It was also shown that effectiveness of 5-HT and acetylcholine in induction of metamorphosis in larvae of bivalve mollusc Ruditapes phillipinarum was low in precompetent pediveligers and significantly increased in competent pediveligers [25]. Besides, the effects of putative dopamine antagonists on metamorphosis in the marine gastropod Crepidula fornicata changed dramatically as larvae aged [87]. The authors suggested that a special sensory system develop in competent pediveligers to recognize specific cues for settlement and metamorphosis [25]. However, they left the question about physiological and molecular mechanisms underlying the observed phenomena open. We speculate that stage-dependent effects of neuroactive substances at pre- and metamorphic stages uncover a molecular mechanism underlying transition to metamorphic competence in aquatic invertebrates with biphasic life cycle. The larva becomes competent when coordinated changes in expression patterns of specific neurotransmitter receptors and their downstream partners take place in the course of development, so the larva becomes sensitive to metamorphic cues. Our results together with the above listed data suggest that 5-HT, dopamine, acetylcholine and other neurotransmitter systems might be involved in this regulation, and these systems might act independently or in coordination. The multiplicity and coordinated action of neurotransmitters and neurotransmitter receptors controlling developmental transitions, settlement and metamorphosis in aquatic invertebrates are still the subject of speculation and require further investigation.

\section{Conclusions}

Our study describes the changes in 5-HT receptors and corresponding $\mathrm{G}$ proteins in the course of development 
of freshwater pulmonate snail $H$. trivolvis. We demonstrate that larval development of $H$. trivolvis includes transition from premetamorphic to metamorphic stages, and share the main features of metamorphosis with free swimming aquatic larvae. We revealed three types of 5-HT receptors (5- $\mathrm{HT}_{1^{-}}, 5-\mathrm{HT}_{4^{-}}$and $5-\mathrm{HT}_{7}$-like) to be expressed and functionally active at premetamorphic (trochophore and veliger) and metamorphic (veliconcha) stages. Stimulation of these receptors modulated cAMP-dependent regulation of cell divisions. Expression patterns of 5-HT receptors and respective $\mathrm{G}$ proteins underwent coordinated changes during development. Thus, expression of $5-\mathrm{HT}_{4}$ - and $5-\mathrm{HT}_{7}$-like receptors and their downstream $\mathrm{G}_{\mathrm{s}}$ protein was down-regulated during the transition of pre- to metamorphic stage, while expression of $5-\mathrm{HT}_{1}$-like receptor and its downstream $G_{i}$ protein was upregulated. In accordance with relative amount of these receptors at different developmental stages, stimulation of 5-HTRs at premetamorphic stages caused developmental retardation, while their stimulation at metamorphic stages caused developmental acceleration. The proposed model suggests a novel molecular mechanism that underlies transition of the larva from premetamorphic (noncompetent) to metamorphic (competent) state.

\section{Additional files}

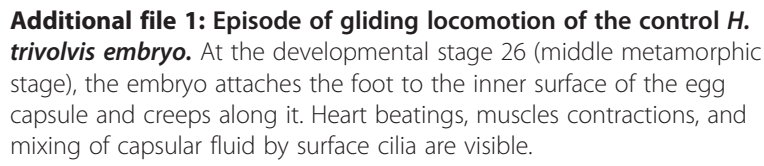

Additional file 2: Episode of rotational swimming of the control $H$. trivolvis embryo. At the developmental stage 26 (middle metamorphic stage), the embryo sometimes detaches from the inner surface of the egg capsule and switches to rotational swimming.

Additional file 3: Episode of rotational swimming of the H.trivolvis embryo after treatment with RS67333. The treatment started at the developmental stage 19 and the embryo was recorded after 84 hours. The embryo is at the stage 23 (premetamorphic veliger) and differs from the controls in smaller size, different shape, and lack of pigmented eyes. No heart beatings and muscles contractions can be seen.

Additional file 4: Episode of gliding locomotion of the H.trivolvis embryo after treatment with 5-CT. The treatment started at the developmental stage 19, and the embryo was recorded after 84 hours. The embryo is already at the stage 27 (the end of metamorphosis). It creeps along the inner surface of the egg capsule using the fully developed foot. The shell covers the whole visceral mass. Heart beatings, pneumostome openings and pigmented eyes at the base of the tentacles are seen.

\section{Abbreviations}

5-CT: 5-carboxyamido-tryptamine maleate; 5-HT: 5-hydroxytryptamine, serotonin; 8-OH-DPAT: 8-Hydroxy-2-dipropylaminotetralin hydrobromide; AC: Adenelyl cyclase; ASO: Apical sensory organ; CAMP: Cyclic adenosine monophosphate; DOl: 2,5-dimethoxy-4-iodoamphetamine; n.e.d.: Normal embryonic development; PB: Phosphate buffer.

\section{Competing interests}

The authors declare that they have no competing interests.

\section{Authors' contributions}

EGP, EEV and KG conceived the project and designed experiments; EEV, MYuK performed pharmacological experiments; KG and EEV performed biochemical and molecular biological experiments; El made the cell division analysis. EEV and LPN performed microscopy and morphological analysis. EEV, KG, EGP and LPN wrote the manuscript. All authors contributed to the manuscript preparation and have read and approved its final version.

\section{Acknowledgements}

Authors would like to thank biological station "Kropotovo" IDB RAS and optical research group of IDB RAS for their technical support. This work was supported by the Deutsche Forschungsgemeinschaft (DFG) through the DFG Grant PO732, Cluster of Excellence REBIRTH and through the Centre of Molecular Physiology of the Brain (CMPB) to EGP, BONFOR O-129.0100 for KG, Russian Foundation for Basic Research grant 14-04-00673 for LPN, Russian Foundation for Basic Research grant 12-04-01510 and Federal governmental program for scientists and teachers 'Innovative Russia' 12.741.12.0155 for EEV. EEV was a recipient of the IBRO and CMPB research fellowships.

\section{Author details}

${ }^{1}$ Department of Neurology, University Hospital of Bonn, Bonn, Germany. 2DFG-Research Center Molecular Physiology of the Brain (CMPB), Göttingen, Germany. ${ }^{3}$ Institute of Developmental Biology RAS, Moscow, Russia. ${ }^{4}$ Department of Experimental Neurocytology, Brain Research Branch, Scientific Center of Neurology, RAMS, Moscow, Russia. ${ }^{5}$ Department of Cellular Neurophysiology, Carl-Neuberg-Str. 1, 30625 Hannover, Germany.

Received: 16 November 2013 Accepted: 21 February 2014 Published: 13 March 2014

\section{References}

1. Marois R, Carew TJ: Ontogeny of serotonergic neurons in Aplysia californica. J Comp Neurol 1997, 386:477-490.

2. Marois R, Croll RP: Development of serotonin like immunoreactivity in the embryonic nervous system of the snail Lymnaea stagnalis. J Comp Neurol 1992, 322:255-265

3. Lauder JM: Neurotransmitters as growth regulatory signals: role of receptors and second messengers. Trends Neurosci 1993, 16:233-240.

4. Buznikov GA, Lambert HW, Lauder JM: Serotonin and serotonin-like substances as regulators of early embryogenesis and morphogenesis. Cell Tissue Res 2001, 305:177-186.

5. Azmitia EC: Modern views on an ancient chemical: serotonin effects on cell proliferation, maturation, and apoptosis. Brain Res Bull 2001, 56(5):413-424

6. Dube F, Amireault P: Local serotonergic signalling in mammalian follicles oocytes and early embryos. Life Sci 2007, 81:1627-1637.

7. Berger M, Gray JA, Roth BL: The expanded biology of serotonin. Annu Rev Med 2009, 60:355-366.

8. Vitalis T, Ansorge MS, Dayer AG: Serotonin homeostasis and serotonin receptors as actors of cortical construction: special attention to the 5- $\mathrm{HT}_{3 \mathrm{~A}}$ and 5- $\mathrm{HT}_{6}$ receptor subtypes. Front Cell Neurosci 2013, 7:93. doi:10.3389/fncel.2013.00093.

9. Whitaker-Azmitia PM: The role of serotonin and serotonin receptors in development of the mammalian nervous system. In Receptors in the Developing Nervous System. Volume 2: Neurotransmitters. Edited by Zagon IS, MacLaughlin PJ. Chapman and Hall; 1993:43-53.

10. Whitaker-Azmitia PM, Druse M, Walker P, Lauder JM: Serotonin as a developmental signal. Behav Brain Res 1996, 73:19-29.

11. Nguyen L, Rigo JM, Rocher V, Belachew S, Malgrange B, Rogister B, Leprince $P$, Moonen $G$ : Neurotransmitters as early signals for central nervous system development. Cell Tissue Res 2001, 305:187-202.

12. Colas JF, Launay JM, Vonesch JL, Hickel P, Maroteaux L: Serotonin synchronises convergent extension of ectoderm with morphogenetic gastrulation movements in Drosophila. Mech Dev 1999, 87:77-91.

13. Fukumoto T, Kema IP, Levin M: Serotonin signalling is a very early step in patterning of the left-right axis in chick and frog embryos. Curr Biol 2005, 15:794-803

14. Schaerlinger $B$, Launay $J M$, Vonesch $J L$, Maroteaux $L$ : Gain of affinity point mutation in the serotonin receptor gene $5-H T_{2 D r o}$ accelerates germband extension movements during Drosophila gastrulation. Dev Dyn 2007, 236:991-999. 
15. Levin M, Buznikov GA, Lauder JM: Of minds and embryos: left-right asymmetry and the serotonergic controls of pre-neural morphogenesis. Dev Neurosci 2006, 28:171-185

16. Heyland A, Reitzel A, Degnan S: Emerging patterns in the regulation and evolution of marine invertebrate settlement and metamorphosis. In Mechanisms of Life History Evolution. Edited by Heyland A, Flatt T. Oxford: Oxford University Press; 2011:29-42.

17. Hadfield MG, Carpizo-Ituarte EJ, del Carmen K, Nedved BT: Metamorphic competence a major adaptive convergence in marine invertebrate larvae. Amer Zool 2001, 41:1123-1131.

18. Schackwitz WS, Inoue T, Thomas JH: Chemosensory neurons function in parallel to mediate a pheromone response in C elegans. Neuron 1996, 17:719-728.

19. Sze JY, Victor M, Loer C, Shi Y, Ruvkun G: Food and metabolic signalling defects in a Caenorhabditis elegans serotonin-synthesis mutant. Nature 2000, 403:560-564

20. Zega G, Pennati R, Fanzago A, De Bernardi F: Serotonin involvement in the metamorphosis of the hydroid Eudendrium racemosum. Int J Dev Biol 2007, 51:307-313.

21. McCauley DW: Serotonin plays an early role in the metamorphosis of the Hydrozoan Phialidium gregarium. Dev Biol 1997, 190:229-240.

22. Mayorova T, Kach J, Kosevich I: Pattern of serotonin-like immunoreactive cells in scyphozoan and hydrozoan planulae and their relation to settlement. Acta Zool 2013, 95: doi: 0.1111/azo.12023.

23. Yamamoto H, Tachibana A, Kawaii S, Matsumura K, Fusetani N: Serotonin involvement in larval settlement of the barnacle, Balanus amphitrite. J Exp Zool 1996, 275:339-345.

24. Couper JM, Leise EM: Serotonin injections induce metamorphosis in larvae of the gastropod mollusc llyanassa obsoleta. Biol Bull 1996, 191:178-186.

25. Urrutia PM, Okamoto K, Fusenati N: Acetylcholine and serotonin induce larval metamorphosis of the Japanese short-neck clam Ruditapes philippinarum. J Shellfish Res 2004, 23:93-100.

26. Zega G, Pennati R, Groppelli S, Sotgia C, De Bernardi F: Dopamine and serotonin modulate the onset of metamorphosis in the ascidian Phallusia mammillata. Dev Biol 2005, 282:246-256.

27. Goldberg Jl, Koehncke NK, Christopher KJ, Neumann C, Diefenbach TJ: Pharmacological characterization of a serotonin receptor involved in an early embryonic behavior of Helisoma trivolvis. J Neurobiol 1994, 25:1545-1557.

28. Koss R, Diefenbach TJ, Kuang S, Doran SA, Goldberg Jl: Coordinated development of identified serotonergic neurons and their target ciliary cells in Helisoma trivolvis embryos. J Comp Neurol 2003, 457:313-325.

29. Goldberg JI, Doran SA, Shartau RB, Pon JR, Ali DW, Tam R, Kuang S: Integrative biology of an embryonic respiratory behaviour in pond snails: the 'embryo stir-bar hypothesis'. J Exp Biol 2008, 211:1729-1736.

30. Mapara S, Parries S, Quarrington C, Ahn KC, Gallin WJ, Goldberg J: Identification molecular structure and expression of two cloned serotonin receptors from the pond snail Helisoma trivolvis. J Exp Biol 2008, 211:900-910

31. Kawahara $H$, Isoai $A$, Shizuri Y: Molecular cloning of a putative serotonin receptor gene from barnacle, Balanus amphitrite. Gene 1997, 184:245-250.

32. Beladjal L, Kierckens K, Mertens J: Pheromones inhibit the hatching of diapausing Anostraca (Crustacea: Branchiopoda). Anim Biol 2007, 57:1-9.

33. Kaha D, Berman Y, Bar-El T: Maternal inhibition of hatching at high population densities in Tigriopus japonicus (Copepoda, Crustacea). Biol Bull 1988, 174:139-144.

34. Miner BG, Donovan DA, Andrews KE: Should I stay or should I go: predator- and conspecific-induced hatching in a marine snail. Oecologia 2010, 163:69-78

35. Voronezhskaya EE, Khabarova MY, Nezlin LP: Apical sensory neurones mediate developmental retardation induced by conspecific environmental stimuli in freshwater pulmonate snails. Development 2004, 131:3671-3680.

36. Voronezhskaia EE, Khabarova MY, Chaban AK, Nezlin LP: Role of chemical signalling in release of motor programs during embryogenesis of freshwater snails Lymnaea stagnalis and Helisoma trivolvis. Rus J Dev Biol 2007, 38:94-104.

37. Beklemishev VN, Kabata Z: Principles of comparative anatomy of invertebrates Volume 2 University of Chicago Press; 1969.

38. Lacalli TC: Apical organs epithelial domains and the origin of the chordate central nervous system. Amer Zool 1994, 34:533-541.
39. Nielsen C: Animal evolution: interrelationships of the living phyla. Oxford: Oxford University Press; 2001

40. Santagata S, Resh C, Hejnol A, Martindale MQ, Passamaneck YJ: Development of the larval anterior neurogenic domains of Terebratalia transversa (Brachiopoda) provides insights into the diversification of larval apical organs and the spiralian nervous system. Evodevo 2012, 3:3. doi:10.1186/2041-9139-3-3.

41. Kempf SC, Page LR, Pires A: Development of serotonin-like immunoreactivity in the embryos and larvae of nudibranch mollusks with emphasis on the structure and possible function of the apical sensory organ. J Comp Neurol 1997, 386:507-528

42. Page LR, Parries SC: Comparative study of the apical ganglion in planktotrophic caenogastropod larvae: ultrastructure and immunoreactivity to serotonin. J Comp Neurol 2000, 418:383-401.

43. Goldberg Jl, Rich DR, Muruganathan SP, Liu MB, Pon JR, Tam R, Diefenbach TJ, Kuang S: Identification and evolutionary implications of neurotransmitter-ciliary interactions underlying the behavioral response to hypoxia in Lymnaea stagnalis embryos. J Exp Biol 2011, 214:2660-2670.

44. Marois R, Carew TJ: The gastropod nervous system in metamorphosis. J Neurobiol 1990, 21:1053-1071.

45. Fischer $\mathrm{AH}$, Henrich $\mathrm{T}$, Arendt D: The normal development of Platynereis dumerilii (Nereididae Annelida). Front Zool 2010, 7:31.

46. Page LR: Apical sensory organ in larvae of the patellogastropod Tectura scutum. Biol Bull 2002, 202(1):6-22.

47. Diefenbach TJ, Koehncke NK, Goldberg Jl: Characterization and development of rotational behavior in Helisoma embryos: role of endogenous serotonin. J Neurobiol 1991, 22:922-934.

48. Burke RD: Pheromonal control of metamorphosis in the pacific sanddollar, Dendraster excentricus. Science 1984, 225:442-443.

49. Hadfield MG, Meleshkevitch EA, Boudko DY: The apical sensory organ of a gastropod veliger is a receptor for settlement cues. Biol Bull 2000, 198:67-76.

50. Morrill JB: Development of the pulmonate gastropod Lymnaea. In Developmental Biology of Freshwater Invertebrates. Edited by Harrison FW, Cowden RR. New York: Alan R Liss Incorporated; 1982:399-483.

51. Mescheriakov VN: The common pond snail Lymnaea stagnalis L. In Animal species for developmental studies. Edited by Detlaf TA, Vassetzky SG. New York: Plenum Press; 1990:69-132.

52. Voronezhskaya EE, Glebov KI, Khabarova MY, Ponimaskin EG, Nezlin LP: Adult-to-embryo chemical signaling in the regulation of larval development in trochophore animals: cellular and molecular mechanisms. Acta Biol Hung Suppl 2008, 59:117-122.

53. Renner U, Glebov K, Lang T, Papusheva E, Balakrishnan S, Keller B, Richter DW Jahn R, Ponimaskin E: Localization of the mouse 5-hydroxytryptamine(1A) receptor in lipid microdomains depends on its palmitoylation and is involved in receptor-mediated signaling. Mol Pharmacol 2007, 72(3):502-513.

54. Voronezhskaya EE, Hiripi L, Elekes K, Croll RP: Development of catecholaminergic neurons in the pond snail Lymnaea stagnalis: I Embryonic development of dopamine-containing neurons and dopamine-dependent behaviors. J Comp Neurol 1999, 404:285-296.

55. Raven CP: Morphogenesis: The Analysis of Molluscan Development. Oxford: Pergamon Press; 1966.

56. Middlemiss DN, Fozard JR: 8-Hydroxy-2-(di-n-propylamino)-tetralin discriminates between subtypes of the $5-\mathrm{HT}_{1}$ recognition site. Eur $\mathrm{J}$ Pharmacol 1983, 90:151-153.

57. Wood M, Chaubey M, Atkinson P, Thomas DR: Antagonist activity of metachlorophenylpiperazine and partial agonist activity of 8-OH-DPAT at the 5-HT(7) receptor. Eur J Pharmacol 2000, 396:1-8.

58. Vleugels R, Lenaerts C, Baumann A, Broeck JV, Verlinden H: Pharmacological characterization of a 5-HT1-type serotonin receptor in the red flour beetle Tribolium castaneum. PLoS One 2013, 8:e65052.

59. Witz P, Amlaiky N, Plassat JL, Maroteaux L, Borrelli E, Hen R: Cloning and characterization of a Drosophila serotonin receptor that activates adenylate cyclase. Proc Natl Acad Sci U S A 1990, 87:8940-8944.

60. Pietrantonio PV, Jagge C, McDowell C: Cloning and expression analysis of a 5HT7-like serotonin receptor CDNA from mosquito Aedes aegypti female excretory and respiratory systems. Insect Mol Biol 2001, 10:357-369.

61. Hobson RJ, Hapiak VM, Xiao H, Buehrer KL, Komuniecki PR, Komuniecki RW: SER-7 a Caenorhabditis elegans $5-\mathrm{HT}_{7}$-like receptor is essential for the 5-HT stimulation of pharyngeal pumping and egg laying. Genetics 2006, 172:159-169. 
62. Baxter G, Morse DE: G protein and diacylglycerol regulate metamorphosis of planktonic molluscan larvae. Proc Natl Acad Sci U S A 1987, 84:1867-1870.

63. Jensen RA, Morse DE: Chemically induced metamorphosis of polychaete larvae in both the laboratory and ocean environment. J Chem Ecol 1990 16:911-930.

64. Pawlik JR: Natural and artificial induction of metamorphosis of Phragmatopoma Lapidosa californica (Polychaeta: Sabellariidae) with a critical look at the effects of bioactive compounds on marine invertebrate larvae. Bull Mar Sci 1990, 46:512-536.

65. Willoughby D, Yeoman MS, Benjamin PR: Inositol-1,4,5-trisphosphate and inositol-1,3,4,5-tetrakisphosphate are second messenger targets for cardioactive peptides encoded on the Lymnaea FMRFamide gene. J Exp Biol 1999, 202:2581-2593.

66. Magnaldo I, Pouysségur J, Paris S: Cyclic AMP inhibits mitogen-induced DNA synthesis in hamster fibroblasts regardless of the signalling pathway involved. FEBS Lett 1989, 245:65-69.

67. Stork PJ, Schmitt JM: Crosstalk between CAMP and MAP kinase signaling in the regulation of cell proliferation. Trends Cell Biol 2002, 12:258-266.

68. Takahashi H, Honma M, Miyauchi Y, Nakamura S, Ishida-Yamamoto A, lizuka $\mathrm{H}$ : Cyclic AMP differentially regulates cell proliferation of normal human keratinocytes through ERK activation depending on the expression pattern of B-Raf. Arch Dermatol Res 2004, 296:74-82.

69. Rocha AS, Paternot S, Coulonval K, Dumont JE, Soares P, Roger PP: Cyclic AMP inhibits the proliferation of thyroid carcinoma cell lines through regulation of CDK4 phosphorylation. Mol Biol Cell 2008, 19:4814-4825.

70. Roger PP, Reuse S, Maenhaut C, Dumont JE: Multiple facets of the modulation of growth by CAMP. Vitam Horm 1995, 51:59-191.

71. Dumaz N, Marais R: Integrating signals between CAMP and the RAS/RAF/ MEK/ERK signalling pathways. Based on the anniversary prize of the Gesellschaft fur Biochemie und Molekularbiologie Lecture delivered on 5 July 2003 at the Special FEBS Meeting in Brussels. FEBS J 2005, 272:3491-3504.

72. Goto H, Tomono Y, Ajiro K, Kosako H, Fujita M, Sakurai M, Okawa K, Iwamatsu A, Okigaki T, Takahashi T, Inagaki M: Identification of a novel phosphorylation site on histone $\mathrm{H} 3$ coupled with mitotic chromosome condensation. J Biol Chem 1999, 274:25543-25549.

73. Hsu JY, Sun ZW, Li X, Reuben M, Tatchell K, Bishop DK, Grushcow JM, Brame CJ, Caldwell JA, Hunt DF, Lin R, Smith MM, Allis CD: Mitotic phosphorylation of histone $\mathrm{H} 3$ is governed by Ipl1/aurora kinase and Glc7/PP1 phosphatase in budding yeast and nematodes. Cell 2000, 102:279-291.

74. Barber CM, Turner FB, Wang Y, Hagstrom K, Taverna SD, Mollah S, Ueberheide B, Meyer BJ, Hunt DF, Cheung P, Allis CD: The enhancement of histone $\mathrm{H} 4$ and $\mathrm{H} 2 \mathrm{~A}$ serine 1 phosphorylation during mitosis and S-phase is evolutionarily conserved. Chromosoma 2004, 112:360-371.

75. Bayne BL: Physiological ecology of marine molluscan larvae. In The Mollusca Volume 3 Development. Edited by Verdonk NH, van den Biggelaar JAM, Tompa AS. New York: Academic; 1983:299-343.

76. Purchon RD: The Biology of the Mollusca. Oxford: Pergamon Press; 1977.

77. Croll RP: Insights into early molluscan neuronal development through studies of transmitter phenotypes in embryonic pond snails. Microsc Res Tech 2000, 49:570-578.

78. Diefenbach TJ, Koss R, Goldberg Jl: Early development of an identified serotonergic neuron in Helisoma trivolvis embryos: serotonin expression de-expression and uptake. J Neurobio/ 1998, 34:361-376.

79. Voronezhskaya $E$, Elekes K: Distribution of serotonin-like immunoreactive neurons in the embryonic nervous system of lymnaeid and planorbid snails. Neurobiology (Bp) 1993, 1(4):371-383.

80. Gifondorwa DJ, Leise EM: Programmed cell death in the apical ganglion during larval metamorphosis of the marine mollusc llyanassa obsoleta. Biol Bull 2006, 210:109-120.

81. Ruiz-Jones GJ, Hadfield MG: Loss of sensory elements in the apical sensory organ during metamorphosis in the nudibranch Phestilla sibogae. Biol Bull 2011, 220:39-46.

82. Heyland A, Moroz LL: Signalling mechanisms underlying metamorphic transitions in animals. Integr Comp Biol 2006, 46(6):743-759.

83. Morse DE, Duncan H, Hooker N, Baloun A, Young G: GABA induces behavioural and developmental metamorphosis in planktonic molluscan larvae. Fed Proc 1980, 39:3237-3241.
84. Trapido-Rosenthal HG, Morse DE: Regulation of receptor-mediated settlement and metamorphosis in larvae of a gastropod mollusc (Haliotis rufescens). Bull Mar Sci 1986, 39:383-392.

85. Pires A, Croll RP, Hadfield MG: Catecholamines modulate metamorphosis in the opisthobranch gastropod Phestilla sibogae. Biol Bull 2000, 198:319-331.

86. Pires A, Guilbault TR, Mitten JV, Skiendzielewski JA: Catecholamines in larvae and juveniles of the prosobranch gastropod Crepidula fornicata. Comp Biochem Physiol C 2000, 127:37-47. Evol Dev 2008, 10: 606-618.

87. Pechenik JA, Li W, Cochrane DE: Timing is everything: the effects of putative dopamine antagonists on metamorphosis vary with larval age and experimental duration in the prosobranch gastropod Crepidula fornicata. Biol Bull 2002, 202:137-147.

88. Sánchez-Lazo C, Martínez-Pita I: Induction of settlement in larvae of the mussel Mytilus galloprovincialis using neuroactive compounds. Aquaculture 2012, 344-349:210-215.

89. Sutherby J, Giardini J-L, Nguyen J, Wessel G, Leguia M, Heyland A: Histamine is a modulator of metamorphic competence in Strongylocentrotus purpuratus (Echinodermata: Echinoidea). BMC Dev Biol 2012, 14: doi:10.1186/1471-213X-12-14.

90. Buznikov GA, Nikitina LA, Voronezhskaya EE, Bezuglov W, Willows DAO, Nezlin LP: Localization of serotonin and its possible role in early embryos of Tritonia diomedea (Mollusca: Nudibranchia). Cell Tissue Res 2003 311:259-266.

91. Christopher KJ, Chang JP, Goldberg Jl: Stimulation of ciliary beat frequency by serotonin is mediated by a $\mathrm{Ca}^{2+}$ influx in ciliated cells of Helisoma trivolvis embryos. J Exp Biol 1996, 199:1105-1113.

92. Gerhardt CC, van Heerikhuizen H: Functional characteristics of heterologously expressed 5-HT receptors. Eur J Pharmacol 1997, 334:1-23.

93. Tierney AJ: Structure and function of invertebrate $5-\mathrm{HT}$ receptors: a review. Comp Biochem Physiol A Mol Integr Physiol 2001, 128:791-804.

94. Loomis WF: cAMP oscillations during aggregation of Dictyostelium. Adv Exp Med Biol 2008, 641:39-48.

95. Nakatsuji T, Sonobe H, Watson RD: Molt-inhibiting hormone-mediated regulation of ecdysteroid synthesis in Y-organs of the crayfish (Procambarus clarkii): involvement of cyclic GMP and cyclic nucleotide phosphodiesterase. Mol Cell Endocrinol 2006, 253:76-82.

96. Rittschof DJ, Maki S, Mitchell R, Costlow JD: Ion and neuropharmacological studies of barnacle settlement. Neth J Sea Res 1986, 20:269-275.

97. Clare AS, Thomas RF, Rittschof D: Evidence for the involvement of cyclic AMP in the pheromonal modulation of barnacle settlement. J Exp Biol 1995, 198:655-664.

98. Yamamoto H, Tachibana A, Matsumura K, Fusetani N: Protein kinase $C(P K C)$ signal transduction system involved in larval metamorphosis of the barnacle, Balanus amphitrite. Zoolog Sci 1995, 12:391-396.

99. Kriegstein AR: Stages in the post-hatching development of Aplysia californica. J Exp Zool 1977, 199:275-288.

100. Strathmann MF, Strathmann RR: An extraordinarily long larval duration of 4.5 years from hatching to metamorphosis for teleplanic veligers of Fusitriton oregonensis. Biol Bull 2007, 213:152-159.

101. Bonar DB, Hadfield MG: Metamorphosis of the marine gastropod Phestilla sibogae Bergh (Nudibranchia: Aeolidiacea) I Light and electron microscopic analysis of larval and metamorphic stages. J Exp Mar Biol Ecol 1974, 16:227-255.

102. Bishop CD, Brandhorst BP: Development of nitric oxide synthase-defined neurons in the sea urchin larval ciliary band and evidence for a chemosensory function during metamorphosis. Dev Dyn 2007, 236(6):1535-1546

103. Bishop CD, Pires A, Norby SW, Boudko D, Moroz LL, Hadfield MG: Analysis of nitric oxide-cyclic guanosine monophosphate signaling during metamorphosis of the nudibranch Phestilla sibogae Bergh (Gastropoda: Opisthobranchia). Evol Dev 2008, 10(3):288-299.

104. Voronezhskaya EE, Elekes K: Expression of FMRFamide gene encoded peptides by identified neurons in embryos and juveniles of the pulmonate snail Lymnaea stagnalis. Cell Tissue Res 2003, 314:297-313.

105. Brinkmann N, Wanninger A: Larval neurogenesis in Sabellaria alveolata reveals plasticity in polychaete neural patterning. Evol Dev 2008, 10:606-618. 
106. Temereva $E$, Wanninger $A$ : Development of the nervous system in Phoronopsis harmeri (Lophotrochozoa, Phoronida) reveals both deuterostome- and protostome-like features. BMC Evol Biol 2012 121: doi:10.1186/1471-2148-12-121.

107. Leise EM, Thavaradhara K, Durham NR, Turner BE: Serotonin and Nitric Oxide regulate metamorphosis in the marine snail llyanassa obsoleta. Am Zool 2001, 41:258-267.

doi:10.1186/1471-213X-14-14

Cite this article as: Glebov et al: Mechanisms underlying dual effects of serotonin during development of Helisoma trivolvis (Mollusca). BMC Developmental Biology 2014 14:14.

\section{Submit your next manuscript to BioMed Central and take full advantage of:}

- Convenient online submission

- Thorough peer review

- No space constraints or color figure charges

- Immediate publication on acceptance

- Inclusion in PubMed, CAS, Scopus and Google Scholar

- Research which is freely available for redistribution 